\title{
Thermal Effect on Bond Strength of Rubberized Concrete Filled Steel Tubular Sections
}

\author{
Hesham M. Fawzy, Suzan A. A. Mustafa*, Ahmed E. AbdEl-Badie \\ Zagarig University, Egypt \\ hesham_fawsy2000@yahoo.com, samustafa@eng.zu.edu.eg, abmedabdie1991@gmail.com
}

\begin{abstract}
This study aims to assess the effect of high temperature on the bond strength of Concrete Filled Steel Tubular (CFST) sections incorporating crumb rubber particles as partial replacement of fine aggregates in concrete core. High daily temperatures; as in hot countries; was considered as well. Push out tests were conducted on 72 CFST specimens with five different concrete mixes. Prior to these tests, 210 concrete specimens were tested to obtain the mechanical properties of rubberized concrete under high temperature gradients. Some of the tests; on CFST sections or concrete specimens; were tested at the desired high temperature, and some others were tested after cooling down. The main variables considered were the crumb rubber replacement ratio, shape of CFST section (circular or square) and temperature gradient. The test results indicated that high temperature reduces the bond strength between steel tube and rubberized concrete core with small percentage of rubber replacement. Recovery in bond strength was observed when the specimens were cooled down. Circular sections showed higher bond strength and ductility on its square counterpart.
\end{abstract}

Keywords. CFST sections; Bond Strength; Rubberized Concrete; Crumb Rubber; Elevated Temperature.

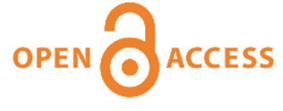

Citation: Fawzy, H. M., Mustafa, S. A. A., AbdEl-Badie A. E., Thermal Effect on Bond Strength of Rubberized Concrete Filled Steel Tubular Sections, Frattura ed Integrità Strutturale, 53 (2020) 353-371.

Received: 08.04 .2020

Accepted: 28.05 .2020

Published: 01.07.2020

Copyright: (C) 2020 This is an open access article under the terms of the CC-BY 4.0, which permits unrestricted use, distribution, and reproduction in any medium, provided the original author and source are credited.

\section{INTRODUCTION}

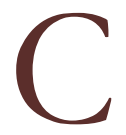

oncrete Filled Steel Tubular (CFST) sections has been widely used in engineering structures. It offers wide vast merits as high strength, ductility, high stiffness and large energy absorption with the combined benefits of concrete and steel. The concrete core adds stiffness to the tube and reduces local buckling. Conversely, the steel tube acts as lateral and longitudinal reinforcement for the concrete core helping it to resist different straining actions and providing confinement for the concrete, thus increasing its strength [1].

Disposal of waste tire has become a serious environmental issue in all parts of the world representing a serious threat to the ecology. The accumulation of waste tires in land fills pollutes the environment and natural resources. An estimated one billion tires reach the end of their useful lives every year and five billion more are expected to be discarded in a regular basis by the year 2030 [2]. Efforts have been taken to identify the potential applications of waste tire rubber in projects of civil 
engineering as a trial to rid the environment of the increased waste tires year after year. One of the possible solutions for using waste tyre rubber is to incorporate it in concrete mixture by replacing some of the natural aggregate. Rubber aggregates can be a lightweight substitute for normal aggregates as its unit weight is less than half of that of normal aggregate [3]. Workability is found to be decreased as the rubber percentage increased [4-6]. Admixtures made with crumb rubber were more workable than those with coarse tire rubber or those with a combination of coarse rubber and fine rubber. Gradual decrease in compressive strength was noticed as the percentage of rubber increased [7-10]. The addition of coarse rubber in concrete lowered the compressive strength more than the addition of fine rubber. The splitting tensile strength of rubberized concrete decreased by addition of rubber particles. Also, it was observed a decrease in compressive strength and split tensile strength of rubberized concrete, while its toughness and ability to absorb fracture energy were improved significantly [11]. Flexural strength decreases as the percentage of rubber increases. This contradiction in behavior depends on size of rubber particles utilized [12]. Recent studies reported a reduction within the compressive strength and tensile strength after fire for concrete containing rubber [13-15]. Major loss of strength occurs during the cooling period [16]. The inclusion of rubber aggregate helps in improving ductility and energy dissipation and reduces the risk of explosive spalling of concrete at elevated temperatures [17]. Guelmine and Benazzouk [18] investigated the performance of crumb rubber mortar when exposed to high temperature of $150^{\circ} \mathrm{C}, 200^{\circ} \mathrm{C}, 300^{\circ} \mathrm{C}$ and $400^{\circ} \mathrm{C}$. They observed that inclusion of rubber particles has a slight effect on the residual properties of concrete up to $300^{\circ} \mathrm{C}$ and significant effect when temperature reaches $400^{\circ} \mathrm{C}$.

Bond between concrete core and steel tube in CFST columns has a very important impact on its performance. In the past few decades, several studies have been performed to study the bond behavior for CFST columns [19-23]. The method of push-out test was adopted to investigate the bond-slip behavior of CFST in many researches. Liu [24] discovered through experimental studies that the strength of concrete has no clear effect on the bond strength of CFST. On the other hand, the results of the study by Lihong and Shaohuai [25] and Qu and Chen [26] showed that the concrete strength clearly influences the bond strength, and the bond strength increases with the increase of concrete strength. Hunaiti [27] tested 21 specimens, after exposed to different temperatures ranging from $50^{\circ} \mathrm{C}$ to $600^{\circ} \mathrm{C}$, to investigate the bond between concrete core and steel tube. It was noted that the loss in bond strength was significantly higher for high temperatures. A specimen tested at $600{ }^{\circ} \mathrm{C}$ showed a $83 \%$ loss in bond strength when compared with the specimen tested at $100{ }^{\circ} \mathrm{C}$. Tao and Han [28] tested the bond strength of CFST sections after exposed to high temperature, the test results indicated that the bond strength between the concrete core and steel tube decreased after exposed to a duration of $90 \mathrm{~min}$ and a strength recovery was found after exposed to a duration of $180 \mathrm{~min}$.

In this research, the effect of different temperature gradients; incorporating high environmental temperature as in hot countries; on bond strength in rubberized CFST sections was studied. Preceding to these tests, the influence of the different high temperatures on compressive, flexural and splitting tensile strengths of rubberized concrete was examined. Five crumb rubber replacement percentages ranging between $0 \%$ to $16 \%$ were incorporated in the concrete mixes. Bond strength was evaluated by conducting push out tests on CFST sections.

\section{EXPERIMENTAL PROGRAM}

\section{General}

total number of 72 CFST specimens were examined. The variables inspected were cross-section type; circular and square; percentage of rubber replacement; $0 \%, 4 \%, 8 \%, 12 \%$, and $16 \%$ of fine aggregate and temperature degree; $25^{\circ} \mathrm{C}, 70^{\circ} \mathrm{C}, 200^{\circ} \mathrm{C}, 400^{\circ} \mathrm{C}$. A summary of all tested specimens is illustrated in Tab.1. The samples were designated according to the following bases: a starting letter of " $\mathrm{S}$ " or " $\mathrm{C}$ " refers to a specimen with square or circular cross section, respectively. The second character " $\mathrm{N}$ " or "R" in the specimen labels refers to a specimen with normal concrete or rubberized concrete, respectively. The numbers; " 4 ", " 8 ", " 12 " or " 16 " in the specimen labels refers to the percentage of rubber; and the following "R", "F" or "P" denote a specimen at room temperature, fire or post-fire, respectively. The numbers " 70 ", " 200 " or " 400 " in the specimen labels refers to temperature degree. The suffixes "a" and "b" distinguish between the specimens of identical pairs tested for reliable results; in most of the tested parameters. In this table, $\mathrm{D}$ is the diameter of a circular section; $\mathrm{B}$ is the width of a square section; ts is the thickness of the steel tube and $\mathrm{T}$ is the temperature. Prior to the CFST tests, 210 samples of concrete with five different concrete mixtures $(0 \%, 4 \%, 8 \%, 12 \%$, and $16 \%$ rubber replacement) were examined. The samples (cubes $10 \times 10 \times 10 \mathrm{~cm}$ ), (prisms $50 \times 10 \times 10 \mathrm{~cm}$ ) and (cylinders $10 \times 20 \mathrm{~cm})$ were carried out, to study and evaluate the mechanical properties of rubberized concrete, and to study the effect of elevated temperatures on rubberized concrete as well. 
Material types and properties

Ordinary Portland cement (CEM I 52.5 N) with specific gravity of 3.15 was used for the concrete mixes in this study. The fine aggregate used was natural sand with specific gravity of 2.6 and fineness modulus of 2.6. The Coarse aggregate used was crushed dolomite graded from $5 \mathrm{~mm}$ to $20 \mathrm{~mm}$, with specific gravity of 2.65 and water absorption rate of $0.85 \%$. All concrete mixes used the same $\mathrm{W} / \mathrm{C}$ of 0.5 . Tab.2 summarizes the used mix proportions. Crumb rubber was used as partial replacement of fine aggregates. The crumb rubber with graded size $\leq 5 \mathrm{~mm}$, specific gravity 0.935 and a melting temperature of $170^{\circ} \mathrm{C}$. To evaluate the mechanical properties of the rubberized concrete under different temperatures gradients, five different concrete mixtures were prepared with rubber rates of: $0,4,8,12$ and $16 \%$ by volume replacement of natural sand. For this purpose, fifteen cubs, fifteen prisms and twelve cylinders were casted for each concrete mix. Six specimens (three specimens after 7 days and three specimens after 28 days from cubs and prisms, moreover three specimens after 28 days from cylinder) were tested without being heated (at the room temperature of $25^{\circ} \mathrm{C}$ ). The remaining nine specimens were divided into three groups and subjected to three temperature exposure conditions $\left(70^{\circ} \mathrm{C}\right.$ for four hours and $200^{\circ} \mathrm{C}$ or $400^{\circ}$ $\mathrm{C}$ for two hours) in an electrical furnace. In the furnace, the specimens were heated to the prescribed temperatures, then specimens were naturally cooled down to room temperature.

\begin{tabular}{|c|c|c|c|c|c|c|c|c|c|}
\hline $\begin{array}{l}\text { Specimen } \\
\text { designation }\end{array}$ & $\begin{array}{l}\text { D or B } \\
(\mathrm{mm})\end{array}$ & $\begin{array}{c}\mathrm{t} \\
(\mathrm{mm})\end{array}$ & $\begin{array}{c}\text { Rubber } \\
\%\end{array}$ & $\begin{array}{c}\text { fcu } \\
(\mathrm{MPa})\end{array}$ & $\mathrm{T}^{\circ} \mathrm{C}$ & $\begin{array}{l}\mathrm{Nu} \\
(\mathrm{kN})\end{array}$ & $\begin{array}{c}\text { tu } \\
(\mathrm{MPa})\end{array}$ & $\begin{array}{c}\mathrm{Su} \\
(\mathrm{mm})\end{array}$ & Curve type \\
\hline CNR-a & 114.3 & 4 & 0 & 33.85 & 25 & 90 & 1.35 & 2.6 & A \\
\hline CNR-b & 114.3 & 4 & 0 & 33.85 & 25 & 85 & 1.27 & 2.5 & B \\
\hline CR4R-a & 114.3 & 4 & 4 & 33 & 25 & 79 & 1.185 & 2.86 & A \\
\hline CR4R-b & 114.3 & 4 & 4 & 33 & 25 & 86 & 1.29 & 0.8 & A \\
\hline CR8R-a & 114.3 & 4 & 8 & 31.9 & 25 & 79 & 1.185 & 2.2 & A \\
\hline CR8R-b & 114.3 & 4 & 8 & 31.9 & 25 & 83 & 1.25 & 0.6 & A \\
\hline CR12R-a & 114.3 & 4 & 12 & 31.2 & 25 & 83 & 1.24 & 2.2 & A \\
\hline CR12R-b & 114.3 & 4 & 12 & 31.2 & 25 & 79 & 1.17 & 2.8 & B \\
\hline CR16R-a & 114.3 & 4 & 16 & 30.6 & 25 & 73 & 1.09 & 0.3 & B \\
\hline CR16R-b & 114.3 & 4 & 16 & 30.6 & 25 & 82 & 1.23 & 0.4 & $\mathrm{~A}$ \\
\hline CNF70 & 114.3 & 4 & 0 & 33.85 & 70 & 78 & 1.17 & 2.7 & $\mathrm{~A}$ \\
\hline CR4F70 & 114.3 & 4 & 4 & 33 & 70 & 75 & 1.125 & 2.88 & $\mathrm{~A}$ \\
\hline CR8F70 & 114.3 & 4 & 8 & 31.9 & 70 & 78 & 1.17 & 2.2 & A \\
\hline CR12F70 & 114.3 & 4 & 12 & 31.2 & 70 & 83 & 1.245 & 2.4 & A \\
\hline CR16F70 & 114.3 & 4 & 16 & 30.6 & 70 & 93.5 & 1.4 & 3 & $\mathrm{~A}$ \\
\hline CNP70 & 114.3 & 4 & 0 & 33.85 & 70 & 89.5 & 1.34 & 2.3 & $\mathrm{~A}$ \\
\hline CR4P70 & 114.3 & 4 & 4 & 33 & 70 & 78 & 1.17 & 2.25 & $\mathrm{~A}$ \\
\hline CR8P70 & 114.3 & 4 & 8 & 31.9 & 70 & 83 & 1.245 & 1.7 & $\mathrm{~B}$ \\
\hline CR12P70 & 114.3 & 4 & 12 & 31.2 & 70 & 93 & 1.4 & 2.28 & $\mathrm{~A}$ \\
\hline CR16P70 & 114.3 & 4 & 16 & 30.6 & 70 & 96 & 1.44 & 3.4 & $\mathrm{~A}$ \\
\hline CNF200 & 114.3 & 4 & 0 & 33.85 & 200 & 72 & 1.08 & 2.18 & A \\
\hline CR4F200 & 114.3 & 4 & 4 & 33 & 200 & 65 & 0.975 & 2.04 & $\mathrm{~A}$ \\
\hline CR8F200 & 114.3 & 4 & 8 & 31.9 & 200 & 70 & 1.035 & 2.5 & A \\
\hline CR12F200 & 114.3 & 4 & 12 & 31.2 & 200 & 89 & 1.33 & 0.717 & $\mathrm{~A}$ \\
\hline CR16F200-a & 114.3 & 4 & 16 & 30.6 & 200 & 93 & 1.395 & 0.794 & $\mathrm{~A}$ \\
\hline CR16F200-b & 114.3 & 4 & 16 & 30.6 & 200 & 95 & 1.42 & 0.88 & $\mathrm{~A}$ \\
\hline CNP200-a & 114.3 & 4 & 0 & 33.85 & 200 & 71 & 1.065 & 1.43 & A \\
\hline CNP200-b & 114.3 & 4 & 0 & 33.85 & 200 & 78 & 1.17 & 0.83 & $\mathrm{~A}$ \\
\hline CR4P200-a & 114.3 & 4 & 4 & 33 & 200 & 74 & 1.11 & 2.9 & $\mathrm{~A}$ \\
\hline CR4P200-b & 114.3 & 4 & 4 & 33 & 200 & 58 & 0.87 & 1.6 & A \\
\hline CR8P00-a & 114.3 & 4 & 8 & 31.9 & 200 & 73.5 & 1.1 & 2.7 & $\mathrm{~A}$ \\
\hline CR8P200-b & 114.3 & 4 & 8 & 31.9 & 200 & 67 & 1 & 2.4 & A \\
\hline CR12P200-a & 114.3 & 4 & 12 & 31.2 & 200 & 99 & 1.458 & 2.13 & $\mathrm{~A}$ \\
\hline CR12P200-b & 114.3 & 4 & 12 & 31.2 & 200 & 92 & 1.38 & 1.39 & $\mathrm{~A}$ \\
\hline CR16P200-a & 114.3 & 4 & 16 & 30.6 & 200 & 89.5 & 1.34 & 1.4 & $\mathrm{~A}$ \\
\hline CR16P200-b & 114.3 & 4 & 16 & 30.6 & 200 & 109 & 1.635 & 1.8 & $\mathrm{~A}$ \\
\hline CNF400 & 114.3 & 4 & 0 & 33.85 & 400 & 62.5 & 0.937 & 2.55 & A \\
\hline CR4F400 & 114.3 & 4 & 4 & 33 & 400 & 69.5 & 1.04 & 2.1 & $\mathrm{~A}$ \\
\hline CR8F400 & 114.3 & 4 & 8 & 31.9 & 400 & 70 & 1.05 & 0.5 & $\mathrm{~A}$ \\
\hline CR12F400 & 114.3 & 4 & 12 & 31.2 & 400 & 89 & 1.33 & 0.629 & A \\
\hline
\end{tabular}




\begin{tabular}{|c|c|c|c|c|c|c|c|c|c|}
\hline CR16F400-a & 114.3 & 4 & 16 & 30.6 & 400 & 112 & 1.68 & 0.76 & A \\
\hline CR16F400-b & 114.3 & 4 & 16 & 30.6 & 400 & 102.5 & 1.536 & 0.936 & A \\
\hline CNP400 & 114.3 & 4 & 0 & 33.85 & 400 & 75 & 1.12 & 2.84 & A \\
\hline CR4P400 & 114.3 & 4 & 4 & 33 & 400 & 71 & 1.065 & 0.7 & A \\
\hline CR8P400 & 114.3 & 4 & 8 & 31.9 & 400 & 60 & 0.9 & 3.52 & A \\
\hline CR12P400 & 114.3 & 4 & 12 & 31.2 & 400 & 88 & 1.32 & 0.7 & A \\
\hline CR16P400-a & 114.3 & 4 & 16 & 30.6 & 400 & 102 & 1.53 & 3.7 & A \\
\hline CR16P400-b & 114.3 & 4 & 16 & 30.6 & 400 & 108.7 & 1.63 & 2.7 & A \\
\hline SNR & 100 & 4 & 0 & 33.85 & 25 & 37 & 0.5 & 0.25 & B \\
\hline SR4R & 100 & 4 & 4 & 33 & 25 & 32 & 0.434 & 4 & $\mathrm{C}$ \\
\hline SR8R & 100 & 4 & 8 & 31.9 & 25 & 36.5 & 0.4 & 2.7 & $\mathrm{C}$ \\
\hline SR12R & 100 & 4 & 12 & 31.2 & 25 & 34 & 0.46 & 0.26 & B \\
\hline SR16R & 100 & 4 & 16 & 30.6 & 25 & 40.8 & 0.55 & 0.25 & B \\
\hline SNF70 & 100 & 4 & 0 & 33.85 & 70 & 30.5 & 0.414 & 0.6 & B \\
\hline SR4F70 & 100 & 4 & 4 & 33 & 70 & 36 & 0.489 & 0.34 & B \\
\hline SR8F70 & 100 & 4 & 8 & 31.9 & 70 & 35 & 0.475 & 0.7 & A \\
\hline SR12F70 & 100 & 4 & 12 & 31.2 & 70 & 40 & 0.54 & 0.24 & B \\
\hline SR16F70 & 100 & 4 & 16 & 30.6 & 70 & 43.75 & 0.6 & 0.34 & A \\
\hline SNF200 & 100 & 4 & 0 & 33.85 & 200 & 26 & 0.35 & 0.72 & B \\
\hline SR16F200 & 100 & 4 & 16 & 30.6 & 200 & 36 & 0.49 & 0.88 & A \\
\hline SNP200 & 100 & 4 & 0 & 33.85 & 200 & 32.3 & 0.438 & 0.487 & B \\
\hline SR4P200 & 100 & 4 & 4 & 33 & 200 & 40 & 0.54 & 0.86 & A \\
\hline SR8P200 & 100 & 4 & 8 & 31.9 & 200 & 34.7 & 0.47 & 0.154 & B \\
\hline SR12P200 & 100 & 4 & 12 & 31.2 & 200 & 70 & 0.95 & 0.76 & B \\
\hline SR16P200 & 100 & 4 & 16 & 30.6 & 200 & 41 & 0.56 & 0.796 & B \\
\hline SNF400 & 100 & 4 & 0 & 33.85 & 400 & 24.5 & 0.33 & 0.52 & B \\
\hline SR4F400 & 100 & 4 & 4 & 33 & 400 & 19 & 0.258 & 1.02 & B \\
\hline SR8F400 & 100 & 4 & 8 & 31.9 & 400 & 41.3 & 0.56 & 2.3 & A \\
\hline SR16F400 & 100 & 4 & 16 & 30.6 & 400 & 32 & 0.434 & 0.2 & B \\
\hline SR4P400 & 100 & 4 & 4 & 33 & 400 & 31.5 & 0.427 & 0.48 & B \\
\hline SR8P400 & 100 & 4 & 8 & 31.9 & 400 & 27.5 & 0.37 & 0.26 & B \\
\hline SR12P400 & 100 & 4 & 12 & 31.2 & 400 & 33.7 & 0.457 & 0.22 & B \\
\hline
\end{tabular}

Table 1: Specimens labels, dimensions, properties and test results

The material properties tests were carried out according to Egyptian Code No. 203 [29]. The slump test was performed after mixing, while compression test was performed after 7 and 28 days using hydraulic testing machine. To measure the flexural capacity, flexure test was carried out on prismatic specimens of $500 \times 100 \times 100 \mathrm{~mm}$ with $400 \mathrm{~mm}$ clear span. This test was performed after 7 and 28 days as well. Splitting tensile strength was carried out using standard cylinder of $100 \mathrm{~mm}$ diameter and $200 \mathrm{~mm}$ height. This test was performed after 28 days using $1000 \mathrm{kN}$ universal testing machine.

The steel tubes with dimensions detailed in Tab.1, were manufactured from mild steel sheets with thickness of $4 \mathrm{~mm}$ and a yield strength of $295 \mathrm{MPa}$. The circular and square sections were chosen so that the $\mathrm{D} / \mathrm{t}$ and $\mathrm{B} / \mathrm{t}$ ratios were 28.6 and 25 respectively. These quite compact sections were utilized to avoid any possible buckling in the steel tube before achieving the ultimate bond strength between the steel tube and the concrete core during the test.

\begin{tabular}{|c|c|c|c|c|c|c|c|c|c|}
\hline \multirow[b]{2}{*}{ Mix ID } & \multirow[b]{2}{*}{$\frac{\cup}{\geqslant}$} & \multirow{2}{*}{$\begin{array}{c}\text { 䔍 } \\
\text { 苞 } \\
\mathrm{kg} / \mathrm{m}^{3}\end{array}$} & \multirow{2}{*}{$\begin{array}{c}\text { Coarse } \\
\text { aggregate } \\
\mathrm{Wt} \\
\mathrm{kg} / \mathrm{m}^{3}\end{array}$} & \multicolumn{2}{|c|}{ Fine aggregate } & \multirow{2}{*}{ 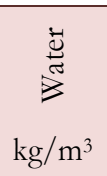 } & \multicolumn{2}{|c|}{ Rubber } & \multirow[b]{2}{*}{$\begin{array}{l}\text { Total } \\
\mathrm{kg} / \mathrm{m}^{3}\end{array}$} \\
\hline & & & & $\begin{array}{c}\text { Volume } \\
\% \text { age }\end{array}$ & $\begin{array}{c}\mathrm{Wt} \\
\mathrm{kg} / \mathrm{m}^{3}\end{array}$ & & $\begin{array}{l}\text { Volume } \\
\% \text { age }\end{array}$ & $\begin{array}{c}\mathrm{Wt} \\
\mathrm{kg} / \mathrm{m}^{3}\end{array}$ & \\
\hline Control mix & 0.5 & 400 & 1110 & 100 & 670 & 200 & 0 & 0 & 2380 \\
\hline C.A-4 \% & 0.5 & 400 & 1110 & 96 & 643.2 & 200 & 4 & 9.6 & 2362.8 \\
\hline C.A-8 \% & 0.5 & 400 & 1110 & 92 & 616.4 & 200 & 8 & 19.2 & 2345.6 \\
\hline C.A-12 \% & 0.5 & 400 & 1110 & 88 & 589.6 & 200 & 12 & 28.8 & 2328.4 \\
\hline C.A-16\% & 0.5 & 400 & 1110 & 84 & 562.8 & 200 & 16 & 38.6 & 2311.4 \\
\hline
\end{tabular}

Table 2: Mix constituent 
Specimens preparation

The steel tube samples were cut from steel pipes of six meters long. Each test specimen had a length L of $240 \mathrm{~mm}$. The two ends of the steel tubes were cut and machined to the designated length, ensuring that the ends were parallel to each other and normal to the sides, to obtain a level surface for regular loading. The inside surface of the steel tubes was cleaned to remove any deposits of oil or dust before casting concrete. All mix proportions were mixed together in a concrete mixer of about $0.1 \mathrm{~m} 3$. The coarse aggregate (dolomite), fine aggregate (sand/fine rubber) and cement were mixed in dry state for about one minute. Mixing water was added gradually to the dry mixed materials during the next two minutes until reaching a homogenous mixture. The concrete was placed by hand in the steel tubes and compacted using tamping rod. The concrete was poured for a length $\mathrm{Li}$ of $190 \mathrm{~mm}$; which is the length of the steel-concrete interface. The air gap of $50 \mathrm{~mm}$ located at the bottom of a sample allowed the slip between the concrete core and steel tube. Push out test of samples was conducted after curing for 28 days. Fig. 1. Shows a general view of the tested circular and square specimens.

\section{Test method}

Push out test was conducted on 72 CFST samples, including 48 circular and 24 square CFST samples. All samples were tested under a Universal Testing Machine (UTM). The samples were positioned vertically in the testing machine, so that the air gap was at the bottom, as shown in Fig. 2. A circular/square steel block with a slightly smaller cross section compared to the inner dimensions of steel tube, was placed on the sample between the top surface of specimen and the load cell. This ensured that the load was applied only to the concrete core and allowed the concrete to move inside the tube during the test. A $1000 \mathrm{kN}$ capacity testing machine was used to conduct the push-out tests, as shown in Fig. 2. Linear Variable Displacement Transducer (LVDT) was used to measure the relative slip between the concrete core and steel tube. During testing, the load was applied at the top of the specimen to the concrete core only and was resisted at the base by the steel tube alone. For performing the fire tests, an electric oven with a thermostat which can attain a maximum temperature of $1300^{\circ} \mathrm{C}$ and a control switch, was used. The used furnace could achieve a high heating rate speed that is somewhat similar to actual fire conditions. The dimensions of the oven hole are $520 \times 520 \times 300 \mathrm{~mm}$, provided with insulator material and the outer body is stiff steel. In order to examine the sensitivity of studied mixes to temperatures effect, the specimens were exposed to three degree of temperatures: $70^{\circ} \mathrm{C}, 200^{\circ} \mathrm{C}$ and $400^{\circ} \mathrm{C}$.

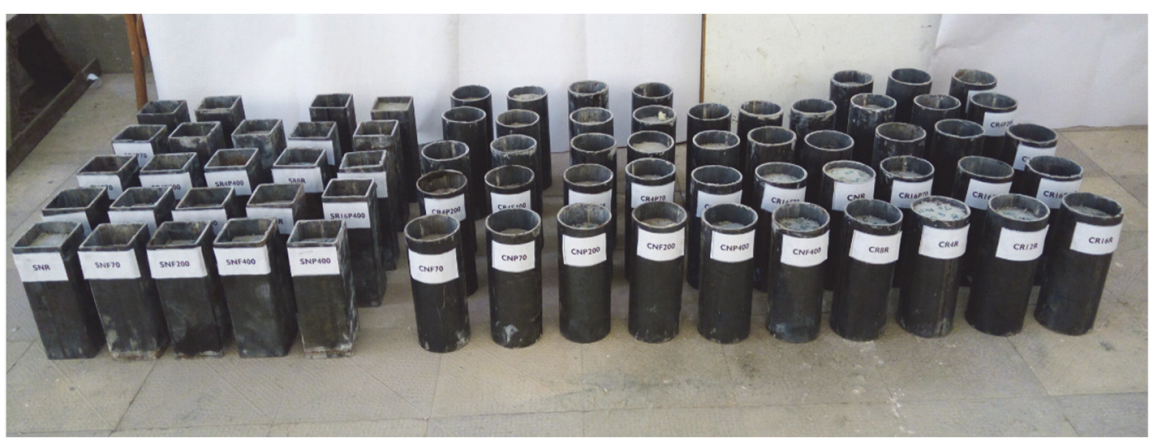

Figure 1: Circular and square CFST specimens

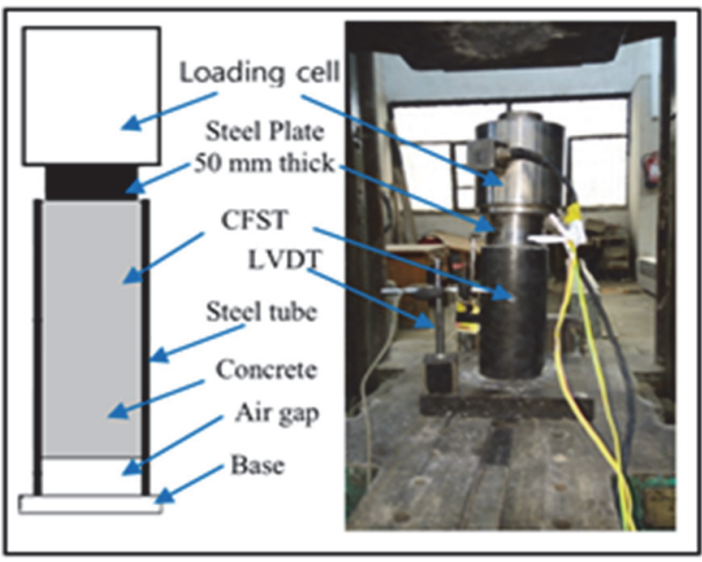

Figure 2: Test setup; Schematic view and specimens in loading machine 


\section{RESULTS AND DISCUSSIONS}

\section{Rubberized Concrete $(\mathrm{R} u C)$ Properties}

decrease in slump was observed when the percentage of rubber content increased. The maximum decrease was A from $75 \mathrm{~mm}$ to $65 \mathrm{~mm}$ when the percentage of rubber increased from $0 \%$ to $16 \%$. The reduction in slump may be attributed to the irregular shape; relatively rough surface of rubber particles and the low inter particle friction between rubber particles and other materials of concrete. Partial substitution of crumb rubber aggregate in concrete caused a gradual decrease in compressive strength at 7 and 28 days, as shown in Fig. 3. RuC with $16 \%$ rubber showed reduction of about $13.35 \%$ and $9.6 \%$ in compressive strength after 7 and 28 days, respectively, compared to conventional concrete mixture. Less reductions were observed in splitting tensile and flexural strength of RuC. Gradual reduction in the tensile strength and flexural strengths were observed with increasing the rubber content until reached $7.75 \%$ and $8.22 \%$, respectively, in concrete with 16\% rubber content. These reductions may be attributed to the low compressive strength of rubber aggregate, weak interfacial bond between rubber aggregate particles and the paste and absence of adhesion between rubber aggregate and cement paste. It was observed that after rupture of samples in tension tests, the rubber aggregate could be easily removed from concrete by fingers, which denoting clearly week bond. Similar observations were found in previous investigations about compressive strength [30-32]; tensile strength [33, 34]; and flexural strength [12, 31, 32, 35].

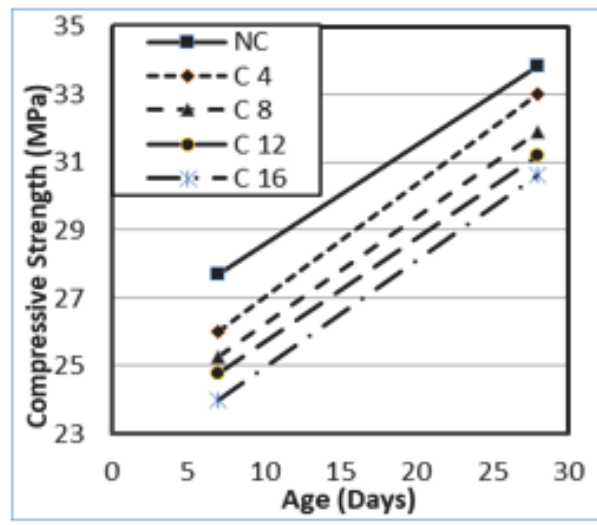

(a)

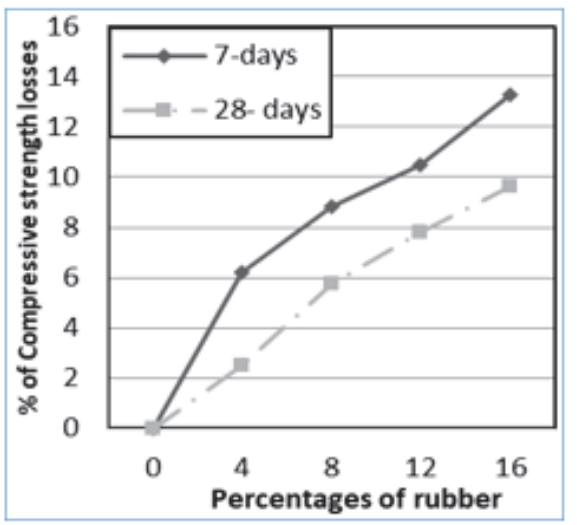

(b)

Figure 3: Rubberized concrete properties, (a) Variation of compressive strength at 7 and 28 days, (b) Loss of compressive strength with different crumb rubber $\%$

\section{Thermal effect on rubberized concrete}

Since fire safety is a very important issue for structures, checking the behaviour of structural elements during fire and postfire stages are essential. Nowadays, daily temperatures have become noticeably high due to global warming. It may sometimes reach $60^{\circ} \mathrm{C}$ and $70^{\circ} \mathrm{C}$, as seen in some areas as the Gulf countries. Therefore, it became necessary to study their impact on structural elements as well. So, specimens were tested after exposure to different temperature gradients; $70^{\circ} \mathrm{C}$, $200^{\circ} \mathrm{C}$, and $400^{\circ} \mathrm{C}$. After removal from the furnace, samples exhibited no signs of explosive spalling. At the target temperature of $70^{\circ} \mathrm{C}$ and $200^{\circ} \mathrm{C}$, there were almost no cracks on the samples' surfaces. At the target temperature of $400^{\circ}$ $\mathrm{C}$ after two hours, micro cracks appeared on the surfaces, as shown in Fig. 4. However, there was a slight decrease in the number of cracks with the increasing percentages of crumb rubber. Similar observations were recognized by other researchers [36]. Rubber particles delayed the onset and propagation of cracks in concrete under high temperatures. Since they are melted under the temperature of $170^{\circ}$ and supply an area for the evaporated water to escape from concrete, consequently, reduce the pore pressure caused by water vapor [37].

In normal concrete and some of rubberized concrete, a slight increase in compressive strength was noticed at $70^{\circ} \mathrm{C}$ and then pursued by reduction with the increase in temperature. The initial increase might be attributed to the drop-in calcium hydroxide and unhydrated area fraction which is beneficial for the microstructure [38]. The highest loss in compressive strength was observed at $400^{\circ} \mathrm{C}$. This might be attributed to that calcium silicate hydrate $(\mathrm{C}-\mathrm{S}-\mathrm{H})$; the main source of concrete strength; decomposes at about $400^{\circ} \mathrm{C}$ [39]. It can be seen that the inclusion of rubber particles reduces the rate of concrete strength loss. This is mainly as a result of rubber particles, once melted at $170^{\circ} \mathrm{C}$, it leaves space for water vapor to escape and thus, helps to release the pore pressure, and that will reduce its damage on the concrete structure. It should 
be noted that the increase of rubber content results in a slight decrease within the compressive strength losses after exposure to high temperature; compared to losses in control mix; but leads to a reduction in concrete strength for the unheated specimens as mentioned above. The loss in splitting tensile and flexural strengths in rubberized concrete were shown to be greater than those of the control mix.

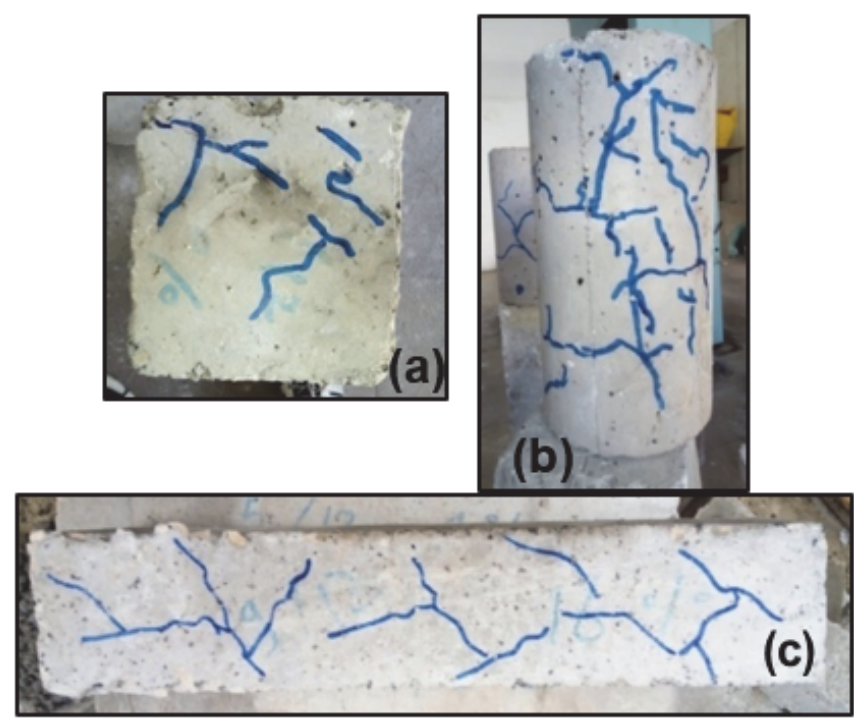

Figure 4: RuC specimens after heating $\left(400^{\circ} \mathrm{C}\right)$ for two hours: (a) Cube, (b) Cylinder, (c) Prism

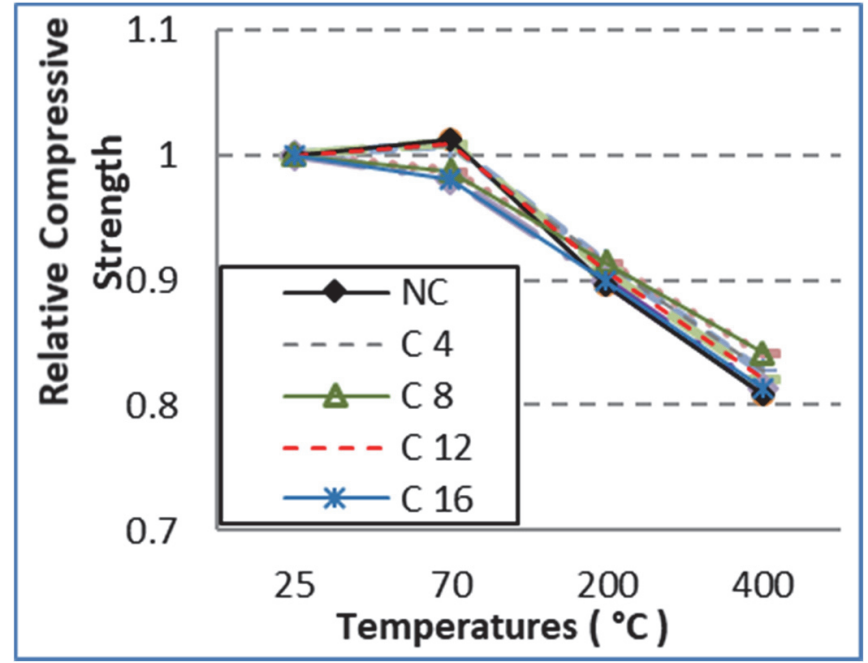

Figure 5: Relative compressive strength of concrete with differe nt percentages of crumb rubber

\section{Concrete Filled Steel Tube (CFST) Sections}

A total number of 72 CFST specimens were tested to study the bond capacity at concrete core-steel tube interface. 48 circular specimens in addition to 24 square specimens were utilized. 15 specimens were tested at room temperature. 15 specimens were tested after exposing to high environmental temperature $\left(70^{\circ} \mathrm{C}\right)$ for five hours. 42 specimens were tested after exposing to $200^{\circ} \mathrm{C}$ and $400^{\circ} \mathrm{C}$ for two hours, some of them were tested under these high temperatures, and some other specimens were tested after cooling, as listed in Tab.1.

Before testing the specimens, no visible gaps were observed between the concrete core and the steel tube. The bond between the concrete core and the steel tube can be considered as a result of three mechanisms. First, natural chemical adhesion between steel and concrete, which is active at the very beginning of loading and is easily broken by excessive relative displacement. It has an elastic behavior and its failure is brittle. Second, physical interlocking of the concrete and steel surfaces at the micro scale. It arises from the roughness of the steel tube surface. It is also known as micro-locking or frictional resistance. Third, macro-locking arises from surface irregularities and correlated to the manufacturing tolerances of internal dimensions of the steel tubes [28, 40-42]. The contribution of three components of the bond strength at different stages of loading is summarized in the idealized force-slip curve in Fig. 6.

\section{Bond-slip behaviour}

Push out tests were performed as described above. In general, slippage starts to occur with increasing the load giving a sign that the chemical adhesion was damaged. According to Virdi and Dowling [43], chemical adhesion diminishes at about 19\% of the ultimate bond strength. Micro-locking begins to participate in the interfacial bond. Slippage increases with increasing the applied load. At large slippage readings, micro-locking is assumed to be damaged, and the interface bond strength depends mainly on macro-locking. The specimens produced a notable sound "snap sound" the moment that the ultimate load was reached. After testing, slight amount of concrete debris were observed around the concrete core on its top surface, as shown in Fig. 8. No buckling in the steel tubes and the main mode of failure was the slippage between the concrete core and steel tube.

For all specimens, applied load and its relative slip (S) between the concrete core and steel tube were recorded. Linear relation was observed at the initial stage until the ultimate bond strength $\left(\tau_{u}\right)$ which was often being used to represent the interfacial bond strength. Eqn. (1) was used to calculate the bond stress;

$$
\tau_{\mathrm{u}}=\mathrm{N}_{\mathrm{u}} / \mathrm{C} \times \mathrm{L}_{\mathrm{i}}
$$


where; $\mathrm{N}_{\mathrm{u}}$ is ultimate load, $\mathrm{L}_{\mathrm{i}}$ is the length of the concrete steel interface and $\mathrm{C}$ is the perimeter of the concrete section in contact with steel tube. Three types of $\tau$-S curves are known for the bond stress-slip behavior, shown in Fig. 7. Type (I) curve, which has an initial linear portion followed by a transitional portion with a falling branch after reaching the ultimate bond strength. Type (II) curve shows quite similar features to type (I) except the existence of the second ascending portion after reaching the ultimate bond strength. Type (III) curve is characterized by the lack of any falling branch

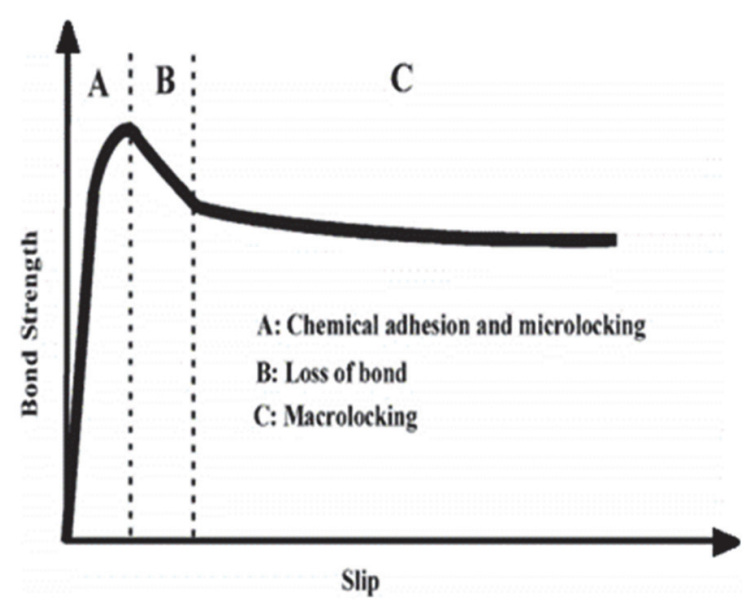

Figure 6: Idealized Bond stress-slip curve at the steel-concrete i nterface [28].

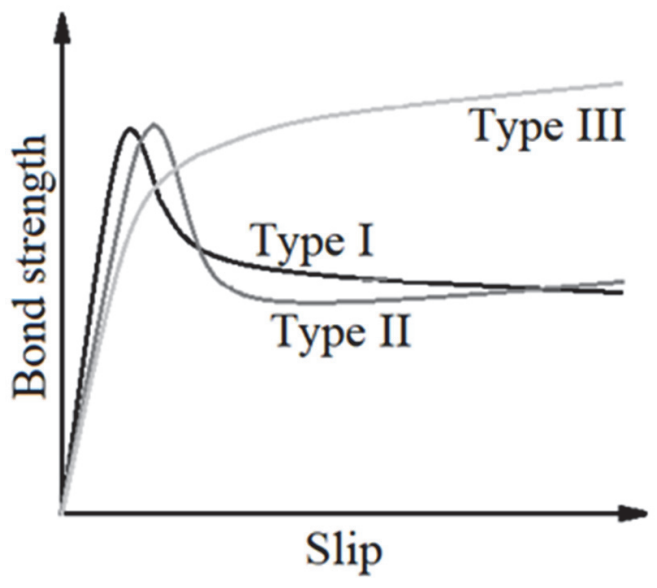

Figure 7: Three type of stress-slip curve [28].
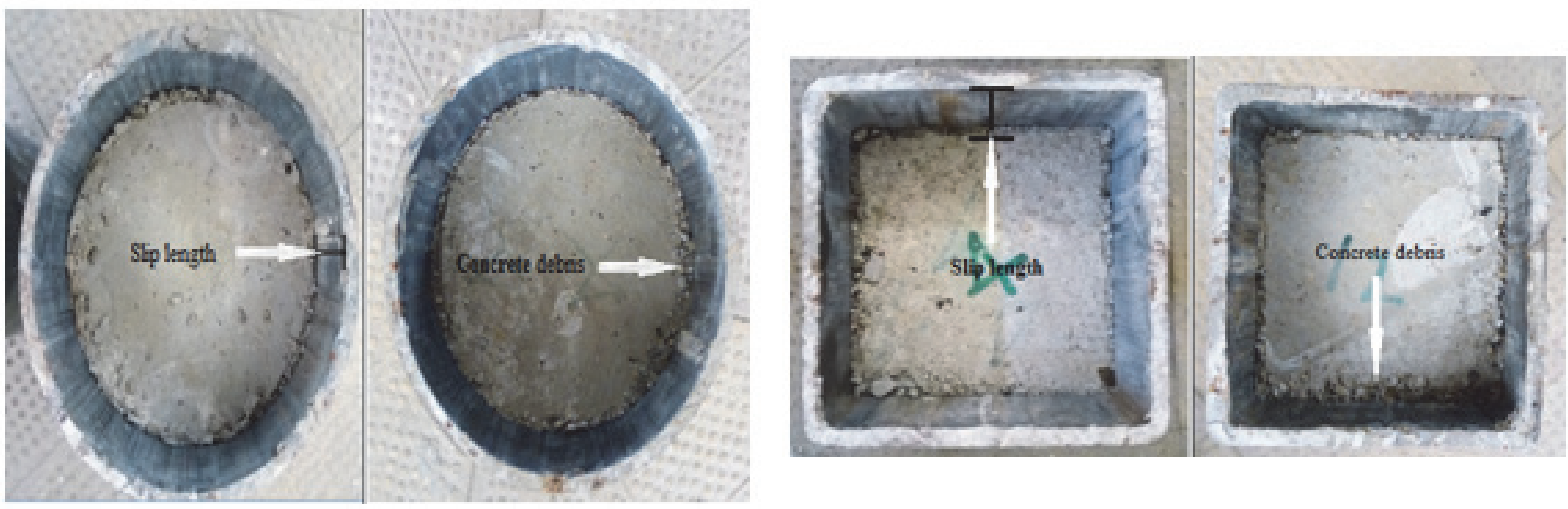

Figure 8: Circular and Square specimens after testing

\section{Bond-slip behaviour at room temperature}

The $\tau$-S curves for rubberized concrete with partial replacement by the percentages of 4, 8, 12 and $16 \%$ and for control mix for circular and square specimens at room temperature are shown in Fig. 9. In normal concrete specimens, the slip initially varied linearly with increasing the bond strength until the bond stress reached about $1 \mathrm{MPa}$ and then followed by transitional portion until reaching the maximum bond strength proceeded by a falling branch in specimen $\mathrm{CNR}$ (a). It reached maximum bond strength of about $1.35 \mathrm{MPa}$ at a slippage value of $2.6 \mathrm{~mm}$. Similar behavior with lower values of maximum bond strength and slippage and a less steeper falling branch were recognized in specimen CNR(b). Specimens with $4 \%$ rubber content; specimen CR4R(a); showed quite similar features to CNR(b), however it had smaller bond stress and higher slippage. It reached maximum bond strength of about $1.185 \mathrm{MPa}$ at a slippage value of $2.86 \mathrm{~mm}$. The slippage of the other specimen $\mathrm{CR} 4 \mathrm{R}(\mathrm{b})$ varied linearly as well, until reaching the maximum bond stress of about $1.29 \mathrm{MPa}$, and then a sudden decrease occurred. For rubberized concrete specimens with $8 \%$ rubber content. Specimen CR8R(a), showed quite similar features to the CNR(a) specimen, however it has smaller bond stress; $1.185 \mathrm{MPa}$; and slippage of $2.2 \mathrm{~mm}$. For the other specimen CR8R(b), there was a sudden decrease in the bond strength after reaching the maximum bond strength. The 
values of maximum bond strength and slippage were $1.25 \mathrm{MPa}$ and $0.6 \mathrm{~mm}$. Increasing rubber content to $12 \%$; specimens CR12R and CR12R(b); showed quite similar features to the CNR(a). However, they had smaller bond stresses of about 1.24 $\mathrm{MPa}$ and $1.17 \mathrm{MPa}$ and values of slippage were $2.2 \mathrm{~mm}$ and $2.8 \mathrm{~mm}$, respectively. With $16 \%$ rubber content, the two specimens showed different behavior. Specimen CR16R(a) showed a linear relation between bond stress and slippage until a maximum bond value of about $1.09 \mathrm{MPa}$, which is corresponding to a slippage value of $0.3 \mathrm{~mm}$. A tiny sudden decrease in the bond stress was observed, then it was followed by an ascending branch (type B curve). A similar initial behavior was observed in specimen CR16R(b). Linear relation between bond stress and slippage until a maximum value of 1.23 MPa with a corresponding $0.4 \mathrm{~mm}$ slippage. A noticeable steep falling branch followed this stage. For these circular CFST specimen, about four- fifths of the specimens demonstrated type (I) curve behavior and only one-fifth demonstrated type (II) curve behavior. No circular specimens showed type (III) curve.

Square CFST specimens showed much smaller bond stress and slippage compared to circular specimens. Normal concrete specimen (SNR), the slip varied linearly until reaching the maximum bond stress of about $0.5 \mathrm{MPa}$ corresponding to a slippage value of $0.25 \mathrm{~mm}$. Thereafter, the bond stress decreased gradually, and the branch tend to be straight. For rubberized concrete specimen with $4 \%$ rubber content (SR4R), the slip initially varied linearly with increasing the bond strength until the bond stress reached $0.35 \mathrm{MPa}$ and then followed by transitional portion until reaching the maximum bond strength. After the ultimate bond strength there was no falling branch. It reached maximum bond strength of about 0.434 $\mathrm{MPa}$ at a slippage value of $0.4 \mathrm{~mm}$. For rubberized concrete specimen with $8 \%$ rubber content (SR8R), the curve like as that in the SR4R, however after the maximum bond strength, the bond increases with slippage. The values of maximum bond strength and slippage were $0.4 \mathrm{MPa}$ and $2.7 \mathrm{~mm}$. For rubberized concrete specimen with $12 \%$ rubber content (SR12R), it showed a quite similar behaviour of SNR, but with a sharp sudden decrease in the bond strength after reaching the maximum bond strength. It reached maximum bond strength of $0.46 \mathrm{MPa}$ at a slippage value of $0.26 \mathrm{~mm}$. For rubberized concrete specimen with $16 \%$ rubber content (SR16R), a linear relation between bond stress and slippage was observed until a maximum stress of $0.55 \mathrm{MPa}$ with a slippage value of $0.25 \mathrm{~mm}$. this stress value was higher than that of specimen SR12R. A bigger decrease was then observed, followed by a constant stress value with increasing the slippage between the concrete core and the steel tube. In general, three-fifth of the square CFST specimens demonstrated type (II) curve behavior, and the remaining two-fifth the specimens demonstrated type (III) curve behavior

\section{Bond-slip behaviour at high daily temperature}

For all the circular specimens tested at high environmental temperature, the slip initially varied linearly with increasing the bond strength and then followed by transitional portion until reaching the maximum bond strength. Thereafter, a falling branch was noticed, as shown in Fig. 10. This behavior was noticed in the specimens tested just after removal from furnace and specimens tested after cooling. It is noteworthy that specimens tested after cooling showed higher ultimate bond strengths than their counterparts tested while just after removal from furnace by about $9.7 \%$. All circular specimens showed (type I) curves except two specimens showed (Type II) curve. Lower ultimate slippage values were recorded for specimens tested after cooling. This means that the behavior of the circular CFST specimens is enhanced when tested after cooling than during exposing to high temperature. Square CFST specimens showed sudden decrease in the bond strength after reaching the maximum values. Much smaller bond stress and slippage records were noticed compared to their circular counterparts. Increasing the rubber percentage in the concrete mix increased the bond strength of the square specimens gradually from $0.414 \mathrm{MPa}$ to $0.6 \mathrm{MPa}$ in specimen containing $16 \%$ rubber replacement. Consequently, the corresponding slippage of the ultimate bond strength decreased from $0.6 \mathrm{~mm}$ to $0.34 \mathrm{~mm}$.

\section{Bond slip behaviour at high temperature}

The $\tau$-S curves for circular and square specimens with different concrete mixes exposed to high temperatures are shown in Fig. 11 and Fig. 12, respectively. Circular specimens showed quite similar feature to type I. Some specimens; as CR8F400, CR12F200, CR12F400 and CR16F200 had a sudden decrease in the bond strength after reaching the maximum value. This behavior was not recognized in specimens tested after cooling. For all the square specimens, they showed quite similar features to type (I) expect for three specimens (SNF200, SR8P200, SR12P400) showed similar features to type B. For the SNF200 specimen, at the ascending portion the bond strength increased until reaching $0.41 \mathrm{MPa}$ which is higher than the ultimate bond strength; $0.35 \mathrm{MPa}$. A noticeable sudden decrease in the shear strength, after reaching the maximum bond strength, was noticed in the three samples containing $16 \%$ rubber. 

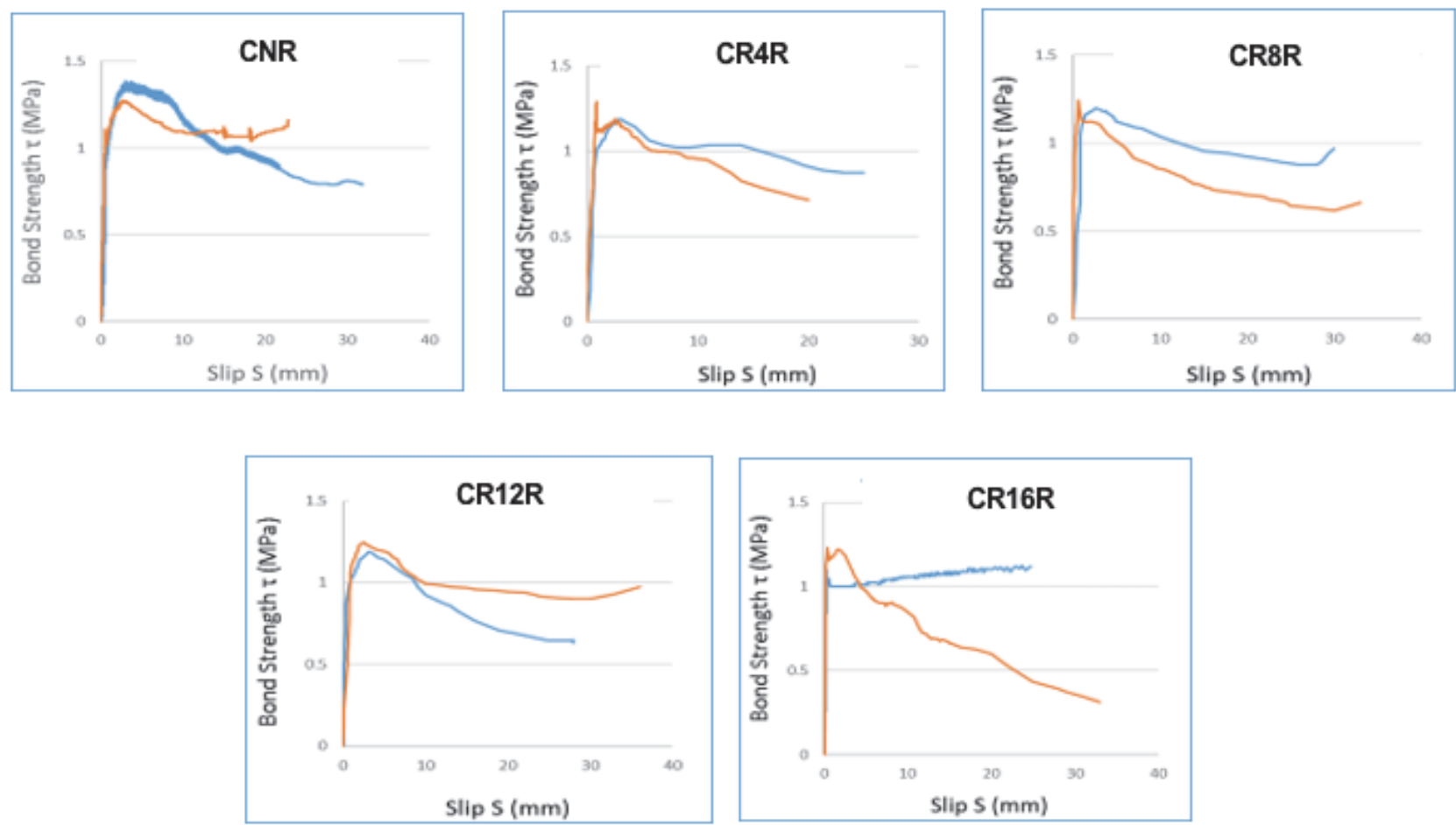

Circular CFST specimens
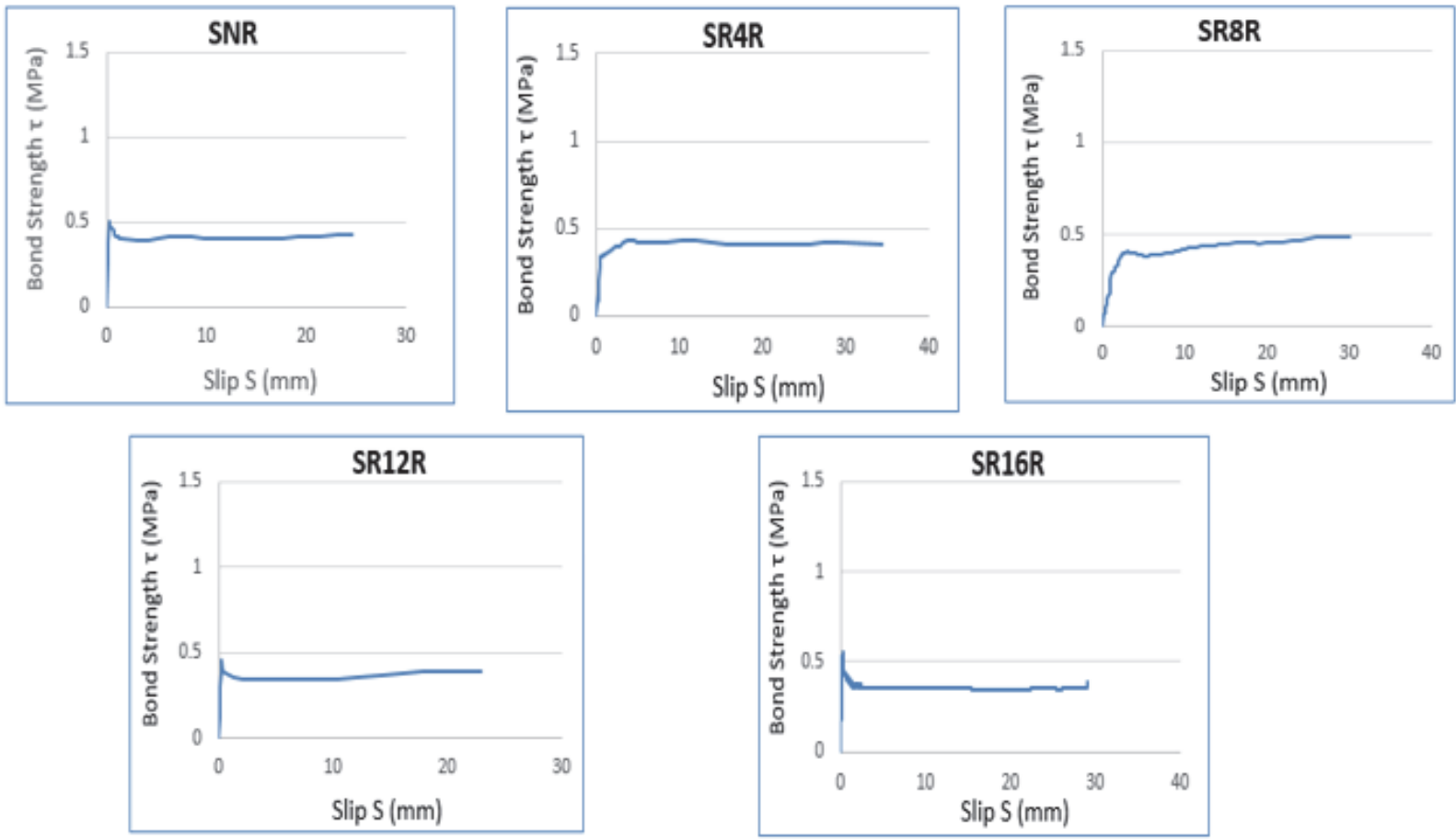

Square CFST specimens

Figure 9: Measured $\tau$-S Curves for Circular and Square Specimens at room temperature 

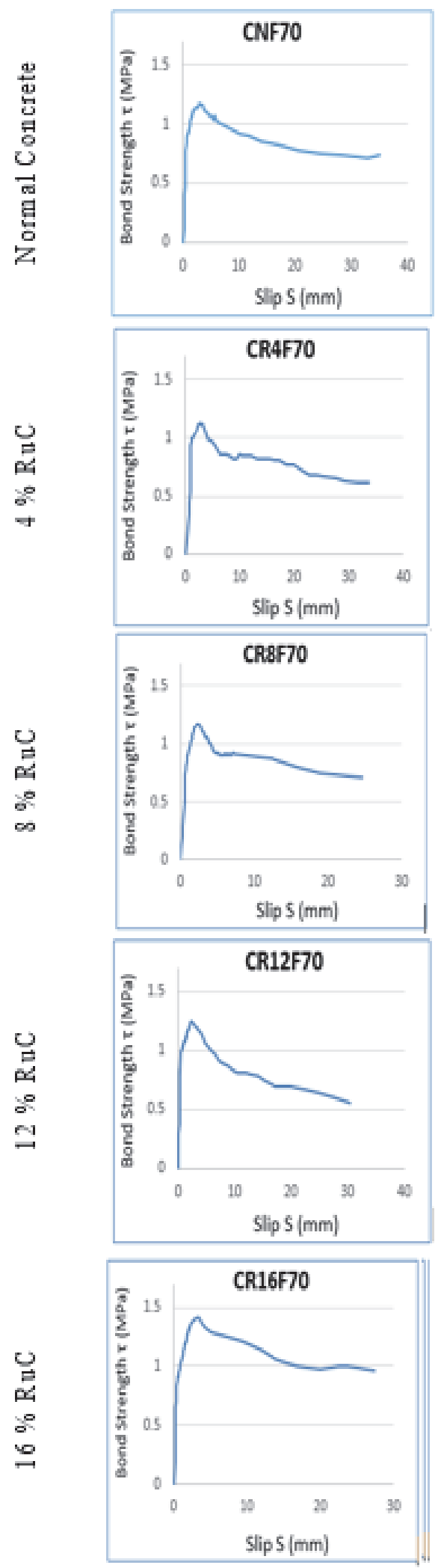
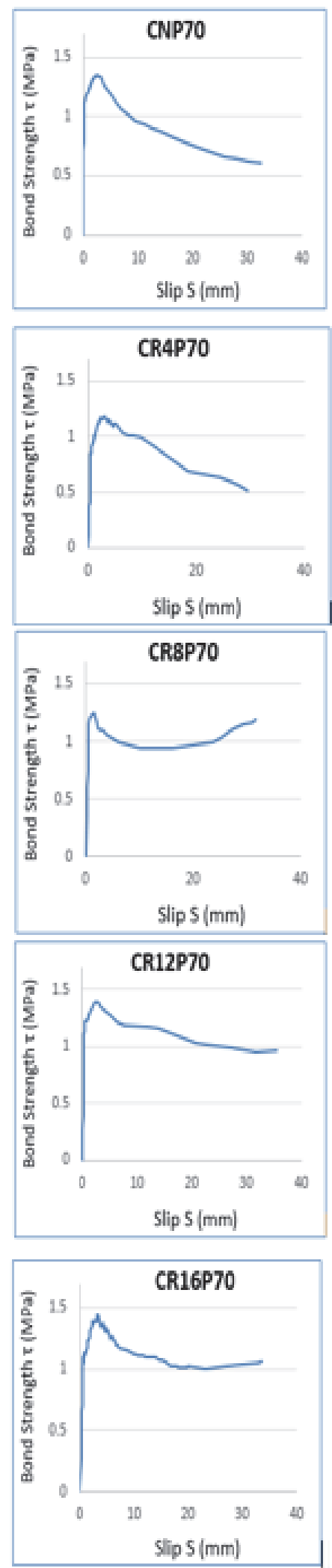
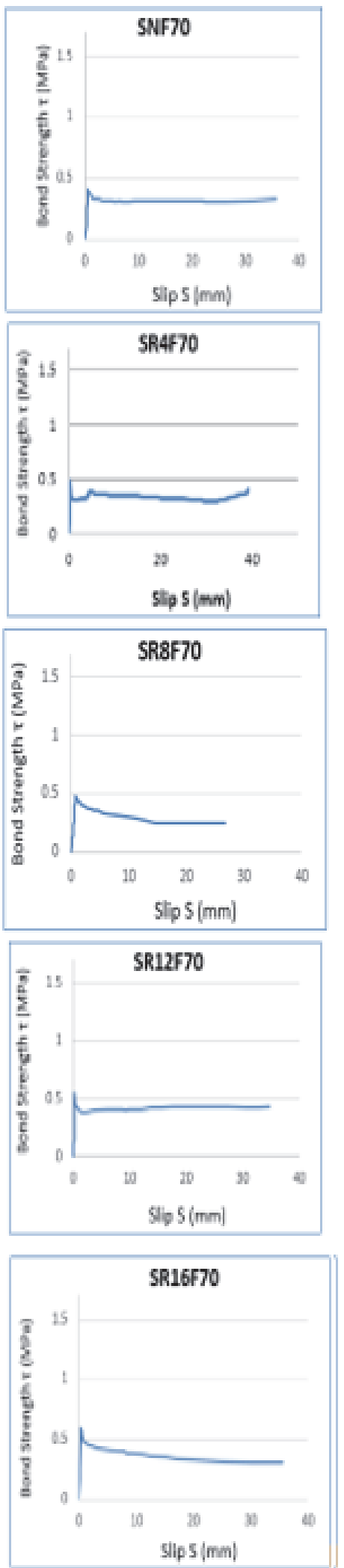

Figure 10: Measured $\tau$-S Curves for Circular and Square Specimens at elevated temperature of $70^{\circ} \mathrm{C}$ for different 
It can be observed that for all types of specimens, at the initial stage of loading, the slippage of the concrete core was very small, and the slip varied linearly with load. When the load increased, the rate of slip increased clearly. After reaching the ultimate load, the curves exhibited a nonlinear change, and the rate of increasing in slippage was faster. After reaching ultimate bond strength, two different cases in the bond-slip curves were observed. When the sum of three mechanisms of bond along the entire interface before the ultimate bond strength was reached, the bond-slip curve showed a clear point at ultimate bond strength followed by a downward trend. Otherwise, there was no clear point at ultimate bond strength and the bond-slip curve did not have downward trend such as the bond-slip curves of SR4R and SR8R in Fig. 12. In some cases, there is a variation in the values of the ultimate bond strength between the two samples for the same sections despite them have been casted in the same conditions such as the bond-slip curves of (CR16R-a and CR16R-b) in Fig. 9 and (CR12P200$\mathrm{a}$ and CR12P200-b) in Fig. 11. This discrepancy can be referred to the variation in the inner surface roughness of the different steel tubes. Similar observation was reported by Roeder [19]. In some specimens; as in CR4R-b and CR16R-b in Fig. 9 and CR12P200-b and CR16F400-b in Fig. 12; a part of the bond strength was recovered after the sudden decrease in bond strength after reaching the ultimate bond strength. similar observation was reported by Parsley and Nezamian [20, 21]. This phenomenon may be explained that the adhesion and friction reduced rapidly before the macro-interlocking could absorb the energy stored in the specimens.

\section{Effect of Rubber Content}

The influence of different percentage of rubber on the bond strength between the concrete and steel tube for circular and square specimens at room temperature are shown in Fig. 13. In general, circular specimens had noticeable higher ultimate bond strength than square specimens for all different crumb rubber percentages. This may be due to increased confinement pressure exerted by the circular section whilst the friction in the square sections is intensified in the corner regions. $16 \%$ rubber content showed the higher reduction in the maximum bond strength by about $11.4 \%$ in circular CFST specimens. While in square CFST specimens, the higher reduction was about $20 \%$ in specimens with $8 \%$ crumb rubber content. The addition of crumb rubber in this type of section increased the maximum bond strengths by $10 \%$ at crumb rubber content of $16 \%$, compared with its counterpart specimen with normal concrete. This may be attributed to that the rubber particles at the interface acted as brakes against slippage between the concrete core and the steel tube. Similar behavior of square CFST specimens was recorded by Abendeh [1] where an increase in the maximum bond strength of about $31 \%$ in specimens containing $20 \%$ crumb rubber content. However, they noticed a reduction in the bond strength of $13 \%$ when the crumb rubber content was increased to $30 \%$. Based on these results it is expected that it is better to maintain the crumb rubber percentage between $16 \%$ and $20 \%$ to improve the bond strength for square specimens at room temperature. One of the most important merits of rubberized concrete is increasing ductility. To quantify the ductility of the tested CFST sections, ductility index (DI) was calculated according to the definition adopted by Abendeh and Han [1, 44]:

$$
D I=\frac{S_{85 \%}}{S_{u}}
$$

where $S_{u}$ is the axial deformation at the maximum bond strength and $S_{85 \%}$ is the axial deformation when the bond strength falls down to $85 \%$ of its maximum value. Trendlines showing the influence of the rubber percentage on the ductility index of the tested circular specimens with different temperature gradients are shown in Fig. 14. Generally, increasing rubber content in concrete increased the ductility of the specimens. In specimens with the same rubber percentage, it was noticed that the ductility and bond strength of the specimens tested after cooling were higher than those of the specimens tested at high temperatures. This may be attributed to the residual expansion of the concrete core after cooling the specimens. For all replacement ratios, circular CFST specimens exhibited more ductile bahaviour than the square specimens. In addition, the micro-locking effect on the bond strength of circular sections is about triple that of the square sections [45]. 

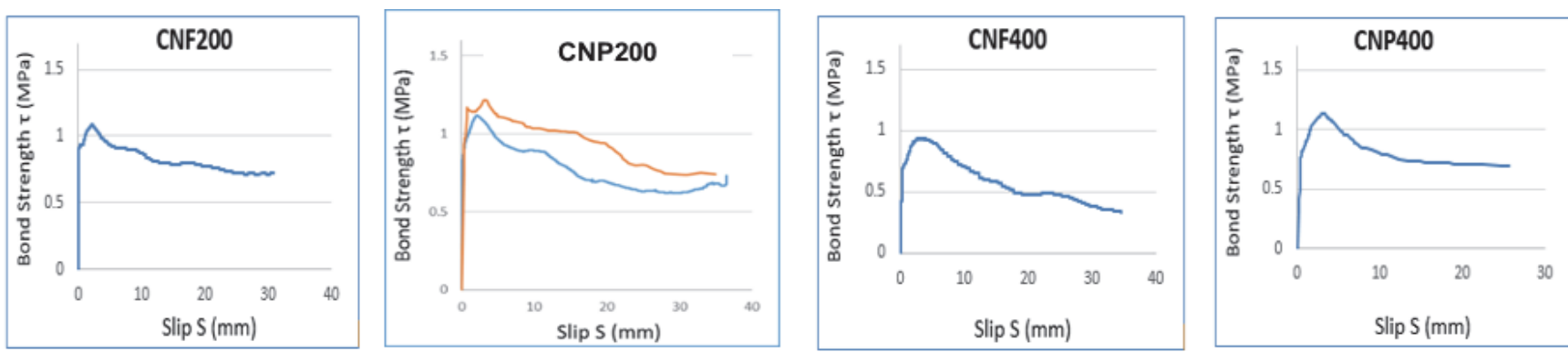

Normal Concrete
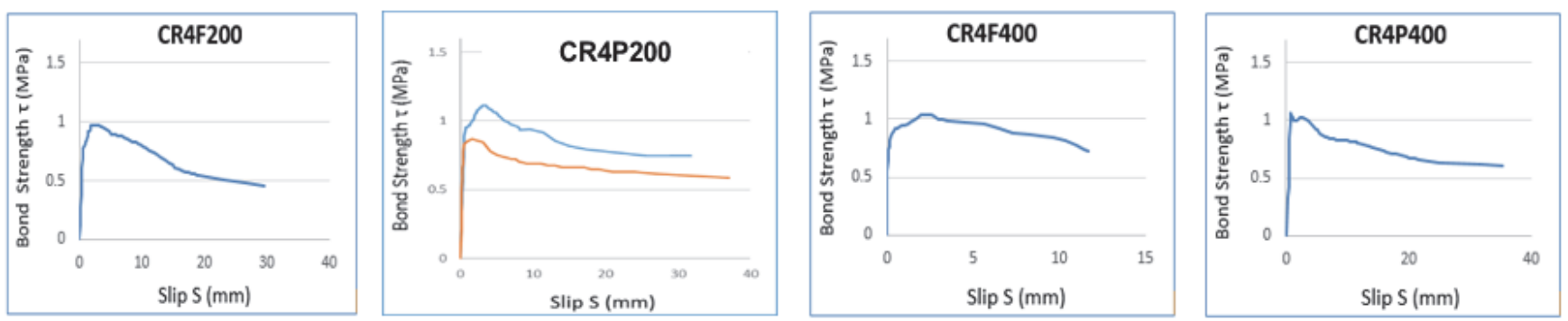

$4 \%$ Rubberized Concrete
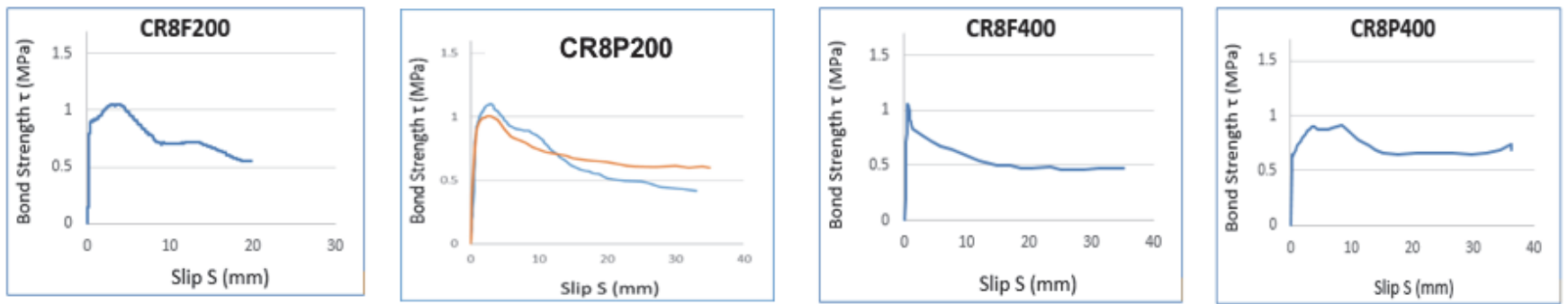

$8 \%$ Rubberized Concrete
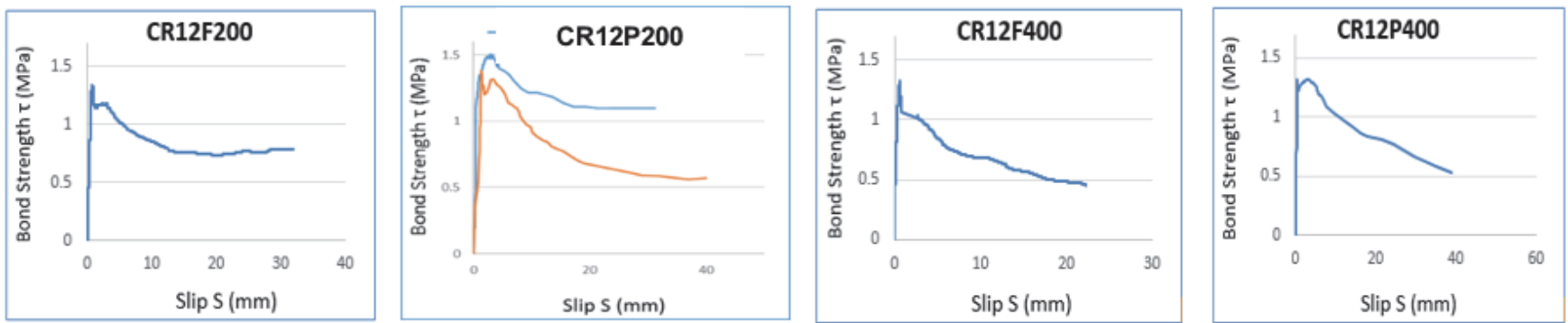

$12 \%$ Rubberized Concrete
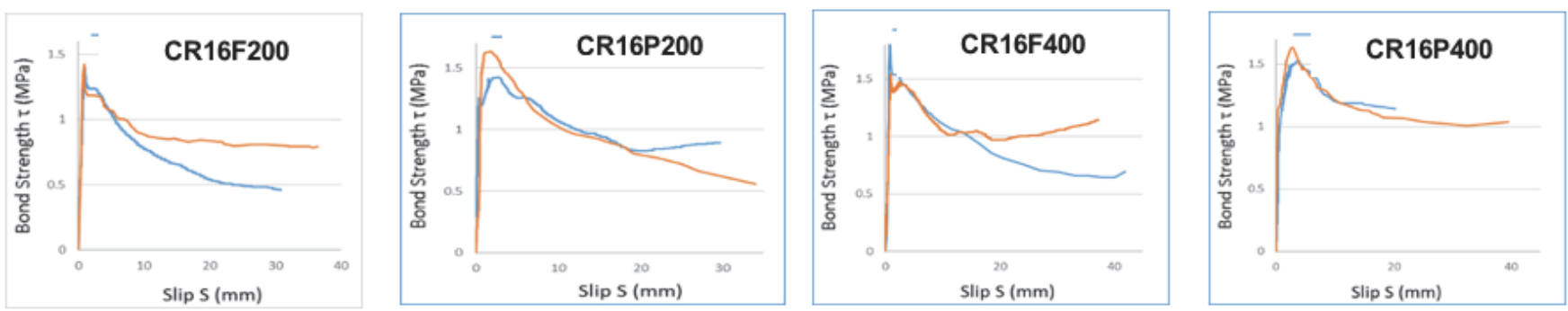

$16 \%$ Rubberized Concrete

Figure 11: Measured $\tau$-S Curves for Circular CFST Specimens at elevated temperature 

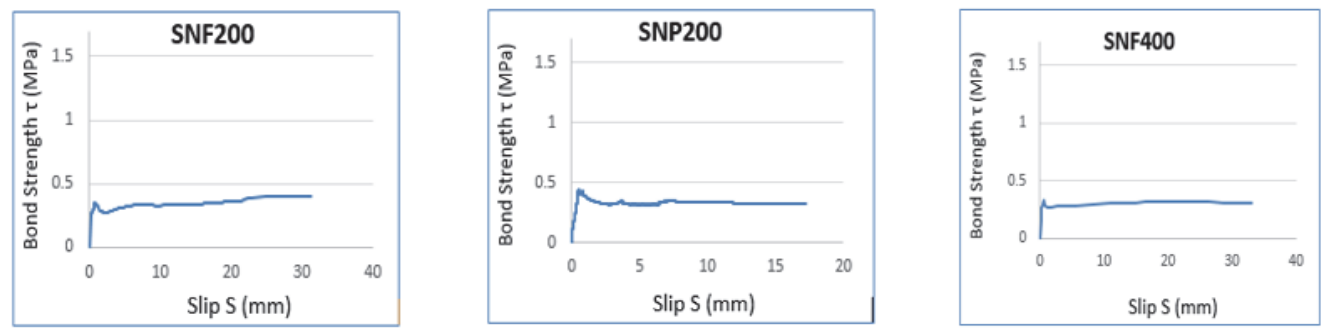

Normal Concrete
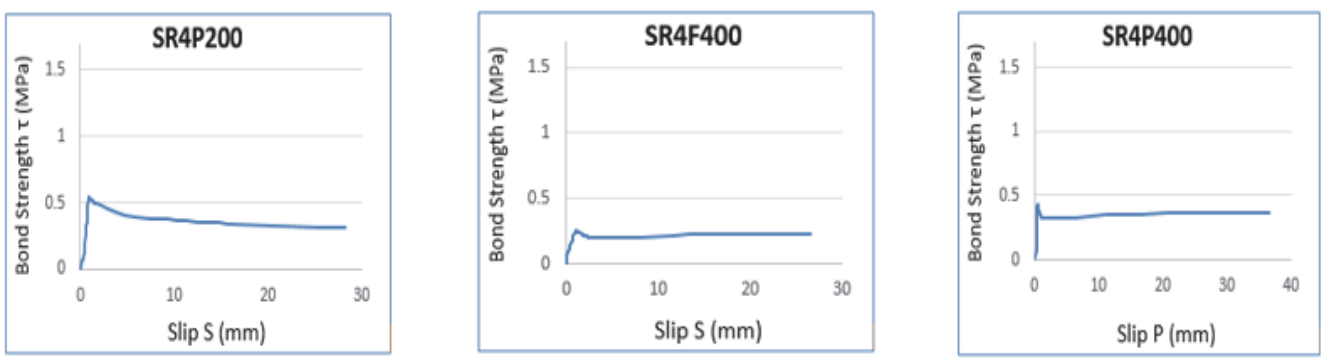

$4 \%$ Rubberized Concrete
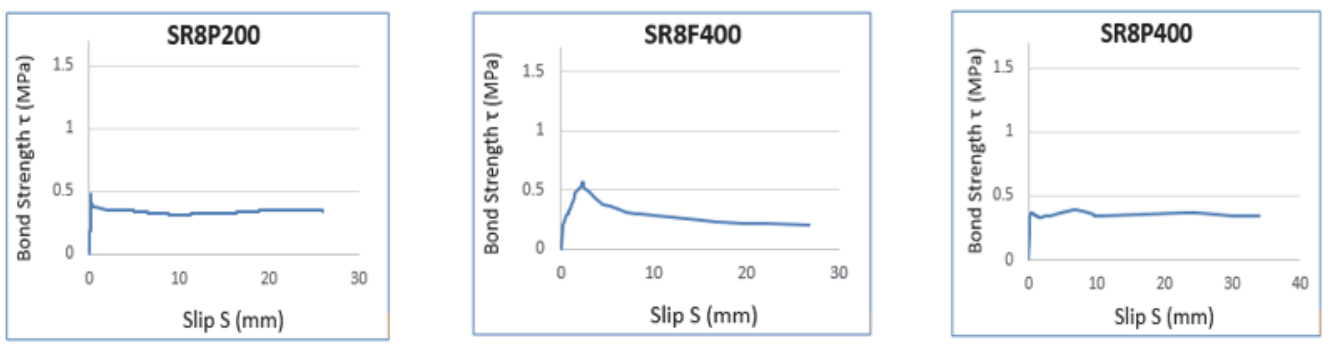

$8 \%$ Rubberized Concrete
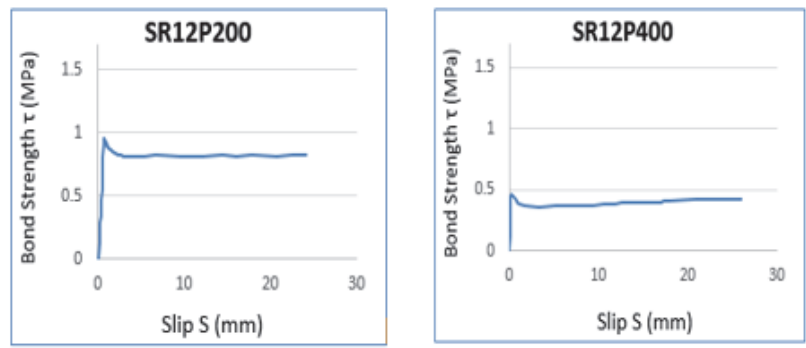

$12 \%$ Rubberized Concrete
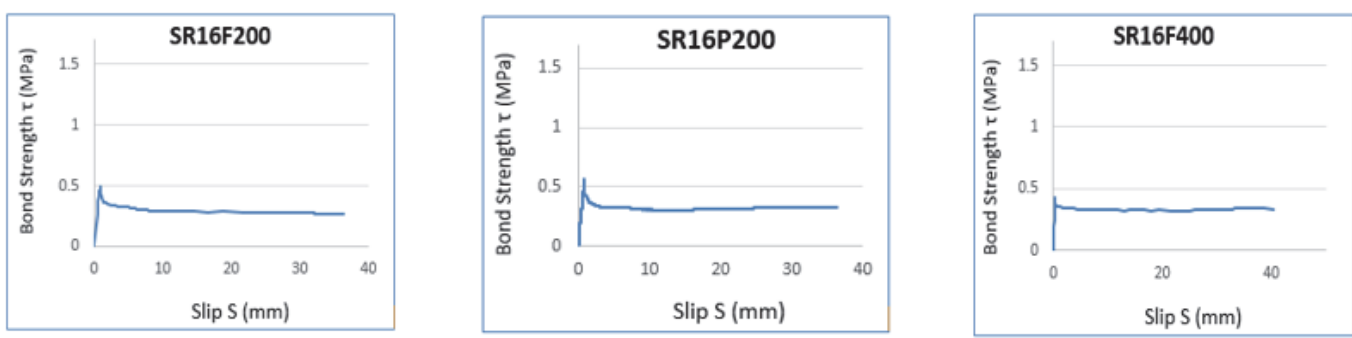

$16 \%$ Rubberized Concrete

Figure 12: Measured $\tau$-S Curves for CFST Square Specimens at elevated temperature 
Effect of Cross-section shape

Although circular and square sections of the CFST specimens had nearly similar cross section area, square sections had much lower bond strength. circular sections showed bond strength of about 2.5 times that of the square sections in all concrete mixes, as shown in Fig. 13 and Fig. 15. At room temperature, the maximum difference between the two section shapes was at a rubber content of $8 \%$; The bond strength of square specimens was lower than that of circular specimens by about $67 \%$. Both sections showed increase in the maximum bond strength with increasing the rubber content at high daily temperature; $70^{\circ} \mathrm{C}$; as shown in Fig. 15. Circular cross sections showed higher bond strength as well at high temperatures; $200^{\circ} \mathrm{C}$ and $400^{\circ} \mathrm{C}$; as shown in Fig. 15 . The maximum difference in bond strength between the two shapes were $62 \%$ and $73 \%$ at $200^{\circ} \mathrm{C}$ and $400^{\circ} \mathrm{C}$ with rubber content of $16 \%$. These high differences may be attributed to the variation in composite actions between square and circular CFST sections. As per many studies conducted lower bond strength can generally be expected in square CFST columns than in circular CFST columns when they have a close cross section areas, as friction can extend all around the perimeter of the inner surface of the circular tube, while in square tube, friction is mainly concentrated near the vicinity of the four corners. Consequently, the whole interfacial area of circular section resists breaking the bond between the concrete core and the inner face of the steel tube [1].

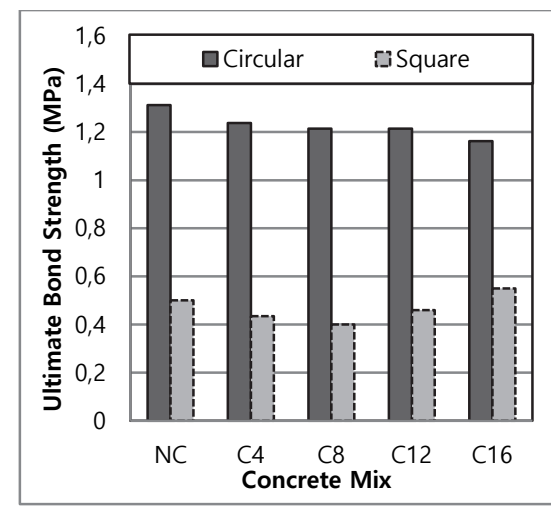

Figure 13: Ultimate bond strength in CFST specimens with different rubber contents at room temperature

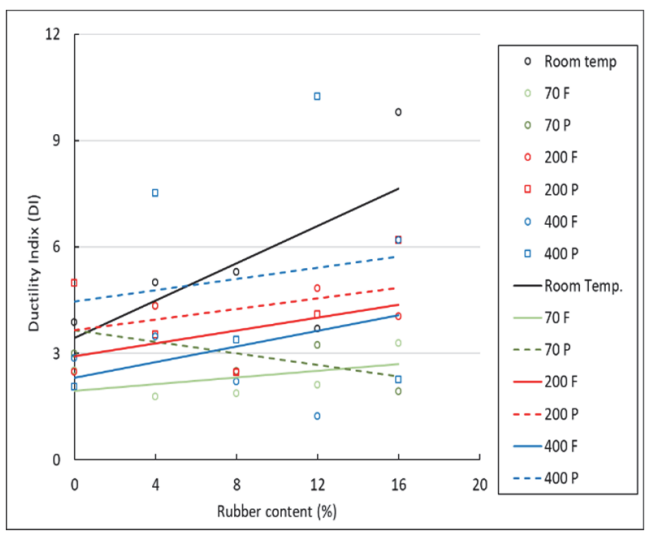

Figure 14: Ductility index of CFST specimens at different temperature gradients
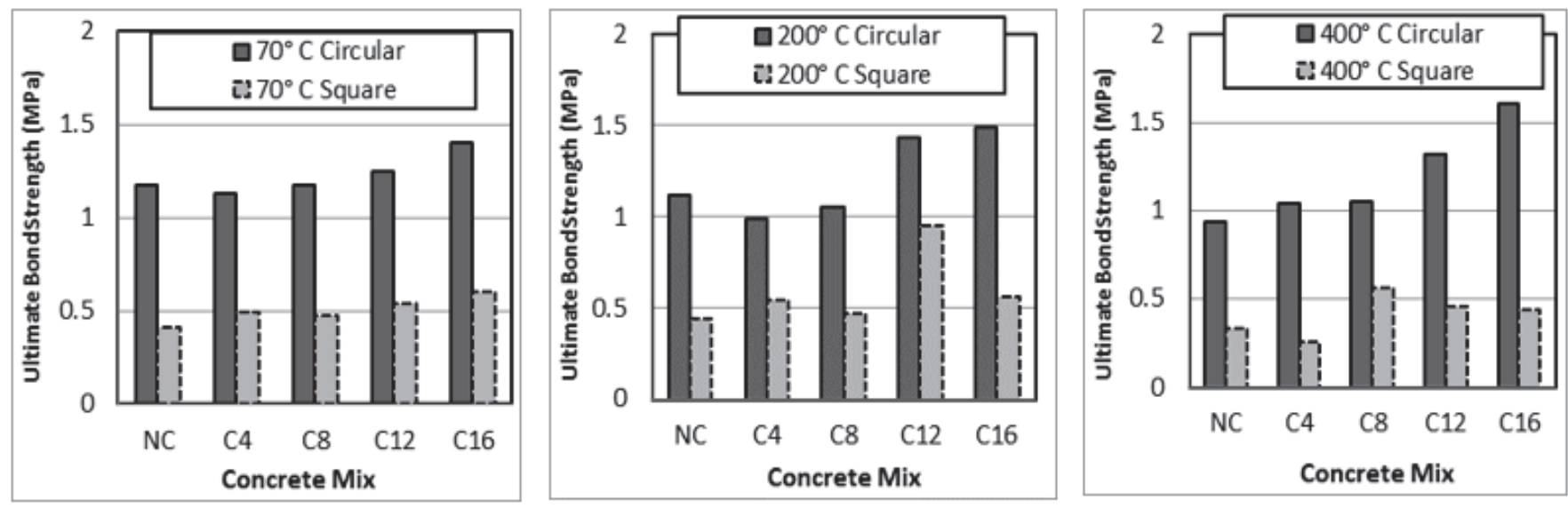

Figure 15: Ultimate bond strength of circular and square CFST column specimens

\section{Effect of Fire and high daily temperature}

High temperature has a significant impact on concrete strength and concrete volume, thus affects the composite action between concrete and the steel tube. Concrete volume change caused by temperature exposure is due to three factors. Remarkable shrinkage in cement paste above $100^{\circ} \mathrm{C}$ after losing evaporable water, considerable expansion in aggregate, and crack formation [46]. Expansion in rubber particles can be added to these factors in the tested specimens. As the fire exposure decreases, the concrete strength and so the thermal expansion coefficient of concrete is lower than that of steel, and thus a gap between the concrete core and steel tube may form, which in turn reduces the bond strength. So, rubberized concrete was expected to show lower bond strength especially when exposed to fire. However, the behavior of specimens 
with different rubber content was variable. During the tests, high intermittent sound was observed in specimens containing $12 \%$ and $16 \%$ rubber tested at temperature of $200^{\circ} \mathrm{C}$ and $400^{\circ} \mathrm{C}$.

Fig. 16. shows the relative bond strength at different exposure temperatures ( $\left.t_{\mathrm{Tu}}\right)$ to the bond strength for the reference temperature of $25^{\circ} \mathrm{C}\left(\mathrm{t}_{25^{\circ} \mathrm{u}}\right)$, for all concrete mixes. Interestingly, the relative bond strength decreases with the increase of temperature in CFST specimens with rubber contents $4 \%$ and $8 \%$ and normal concrete, while it increased in specimens containing higher rubber percentages. Increasing rubber content in concrete decreases the concrete compressive strength and consequently decreases the bond strength. Meanwhile, high temperature causes expansion in rubber particles, as noticed at the surface of the concrete specimens in Fig. 17, and expansion in other components of concrete as well. This increase may be attributed to that the volume of the rubber after melting is increased and come out of the surface of concrete which in turns increase the friction between the concrete core and the steel tube and act as brakes against the movement of the rubberized concrete core. This may explain the high intermittent sound observed during testing these specimens. In low rubber content, the decrease in bond strength due to low compressive strength was more effective than the increase in bond strength due to material expansions. While, the contrast was noticed in specimens with high percentages of rubber particles; as in $12 \%$ and $16 \%$ rubber content. The friction rate increases, resulting in the rate of increase in bonding stress because of rubber particles overcame the reduction in bonding stress due to the decrease in compressive strength. So, in these high ratios of rubber content, the relative bond strength increased with temperature.

Bond strengths of specimens tested after cooling down (post-fire) were higher than their counterparts tested at fire. Two main reasons can be assumed to explain this. During cooling, micro cracks are formed and thus can lead to a radial expansion of concrete, which in turns increase the contact pressure between the concrete core and steel tube and increase friction resistance. On the other hand, after cooling, the concrete recovers apart of the lost strength in addition to the residual expansion of concrete increases the bonding between the concrete core and steel tube. Moreover, concrete may absorb some moisture, and this also affects the size of the sample and thus increases the bonding strength. However, this might not be an effective parameter in CFST specimens due to the existence of the steel tube around concrete.

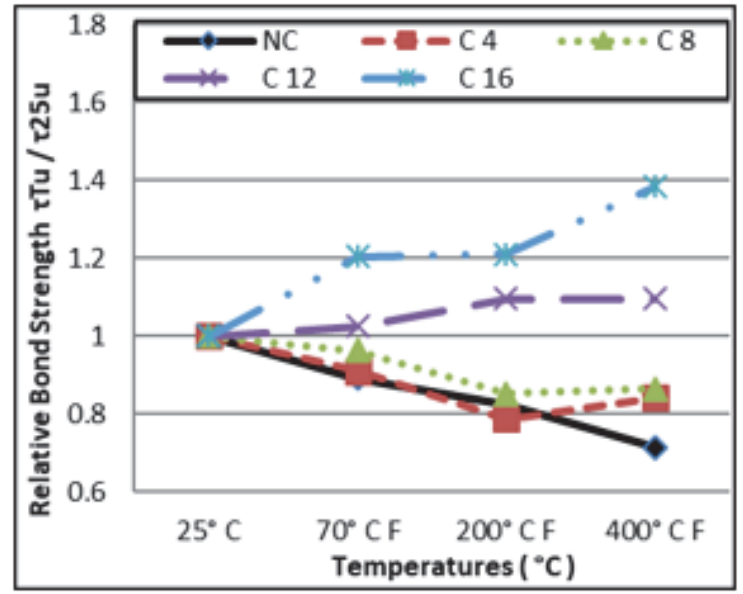

(a) At high temperature

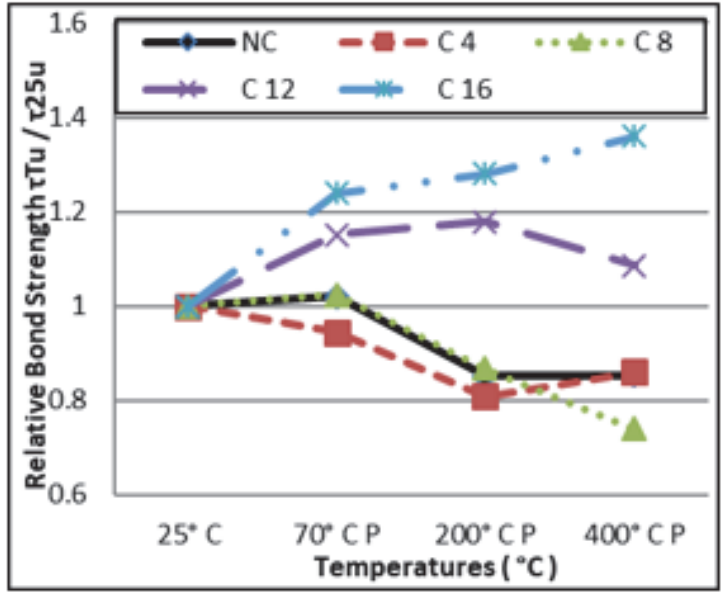

(b) After cooling down

Figure 16: Effect of temperature on Relative Bond strength

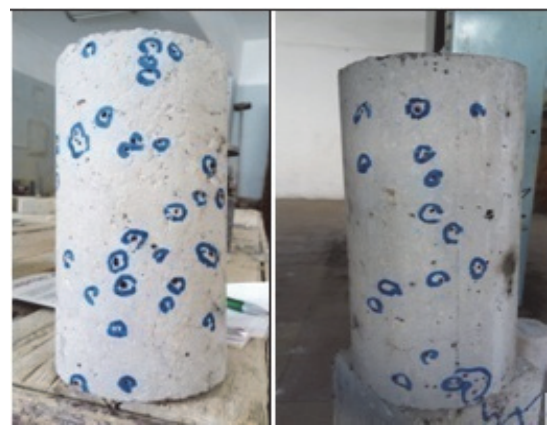

Figure 17: Concrete specimens after exposure to fire 


\section{CONCLUSIONS}

A

n experimental program concerning the effect of high temperature on the characteristics of rubberized concrete and the bond behavior of concrete filled steel tubular sections was discussed in this research. The following conclusions can be outlined based on this study:

- Partial substitution of crumb rubber aggregate in concrete caused gradual decrease in compressive, tensile and flexural strengths of concrete. The degree of reduction depended on the replacement ratio of the rubber aggregates. The effect of fine rubber aggregate on concrete tensile and flexural strength was less than its effect on compressive strength.

- Under high temperature, crumb rubber helps to relieve the inception and growth of cracks in concrete. The inclusion of rubber particles reduces the rate of compressive, splitting tensile and flexural strengths loss.

- Circular rubberized CFST sections had more bond strength and ductility compared to square specimens. Partial substitution of crumb rubber aggregate in concrete caused a gradual decrease in bond strength of concrete. The degree of reduction depended on the replacement ratio of the rubber aggregates.

- Exposure of rubberized CFST sections to a temperature of $70^{\circ} \mathrm{C}$; as in hot countries; caused a slight decrease in bond strength for less amounts of rubber content, however higher content of rubber improves the bond strength. A bond strength recovery was observed after cooling the specimens down.

- The increase in rubber replacement ratio in rubberized CFST sections to $12 \%$ and $16 \%$ enhanced the bond strength in fire and post fire conditions. Less amounts of rubber content caused reduction in the bond strength during exposing to high temperature and after cooling down.

- Strength and ductility recovery were observed in rubberized CFST specimens tested after cooling from exposing to different degrees of high temperature.

\section{ACKNOWLEDGMENTS}

he research described in this paper was financially supported by the Faculty of Engineering, Zagazig University.

\section{REFERENCES}

[1] Abendeh, R., Ahmad, H.S. and Hunaiti, Y.M. (2016). Experimental Studies on the Behavior of Concrete-Filled Steel Tubes Incorporating Crumb Rubber, Journal of Constructional Steel Research. 122, 251-260.

DOI: 10.1016/j.jcsr.2016.03.022

[2] Torgal, P., Ding, F.Y. and Jalali, S. (2012). Properties and Durability of Concrete Containing Polymeric Wastes (Tyre Rubber And Polyethylene Terephthalate Bottles): An Overview, Construction and Building Materials, 30, 714-724. DOI: 10.1016/j.conbuildmat.2011.11.047

[3] Siringi, G., Abolmaali, A. and Aswath, P.B., (2015). Properties of Concrete With Tire Derived Aggregate Partially Replacing Coarse Aggregates, The Scientific World Journal, 2015, ID 863706.

DOI: $10.1155 / 2015 / 863706$

[4] Batayneh, M.K., Marie, I. and Asi, I., (2008). Promoting the Use of Crumb Rubber Concrete in Developing Countries, Waste management, 28(11), 2171-2176. DOI: 10.1016/j.wasman.2007.09.035

[5] Yüksel, İ., Siddique, R. and Özkan, Ö. (2011). Influence of High Temperature on The Properties of Concretes Made with Industrial By-Products as Fine Aggregate Replacement, Construction and building materials, 25(2), 967-972. DOI: 10.1016/j.conbuildmat.2010.06.085

[6] Gintautas, S., Audrius, G. and Benjaminas, C., (2007). Deformation Properties of Concrete with Rubber Waste Additive, Material Science, 13(3), 219-223.

[7] Al-Tayeb, M., Abu Bakar, B.H., Akil H.M. and Ismail, H., (2013). Performance of Rubberized and Hybrid Rubberized Concrete Structures Under Static and Impact Load Conditions, Experimental Mechanics, 53(3), 377-384.

DOI 10.1007/s11340-012-9651-z. 
[8] Wang, H.Y., Chen, B.T. and Wu, Y.W. (2013). A Study of The Fresh Properties of Controlled Low-Strength Rubber Lightweight Aggregate Concrete (CLSRLC), Construction and Building Materials, 41, 526-531.

DOI: $10.1016 /$ j.conbuildmat.2012.11.113.

[9] Yung, W.H., Yung, L.C. and Hua, L.H. (2013). A Study of the Durability Properties of Waste Tire Rubber Applied to Self-Compacting Concrete, Construction and Building Materials, 41, 665-672. DOI: $10.1016 /$ j.conbuildmat.2012.11.019.

[10] Xue, J. and Shinozuka M., (2013). Rubberized Concrete: A Green Structural Material with Enhanced EnergyDissipation Capability, Construction and Building Materials, 42, 196-204. DOI: 10.1016/ j.conbuildmat.2013.01.005.

[11] Shu, X. and Huang, B., (2014). Recycling of Waste Tire Rubber in Asphalt and Portland Cement Concrete: An Overview, Construction and Building Materials, 67, 217-224. DOI: 10.1016/j.conbuildmat. 2013.11.027.

[12] Aiello, M.A. and Leuzzi, F. (2010). Waste Tyre Rubberized Concrete: Properties at Fresh and Hardened State, Waste Management, 30(8), 1696-1704. DOI: 10.1016/j.wasman.2010.02.005.

[13] Correia, J., Marques, A.M., Pereira, C.M.C., Brito, J., (2012). Fire Reaction Properties of Concrete Made with Recycled Rubber Aggregate, Fire and Materials, 36(2), 139-152. DOI: 10.1002/fam.1094.

[14] Marques, A., Correia, J. and De Brito, J. (2013). Post-Fire Residual Mechanical Properties of Concrete Made with Recycled Rubber Aggregate, Fire Safety Journal, 58, 49-57. DOI: 10.1016/j. firesaf.2013.02.002.

[15] Mousa, M.I., (2017). Effect of Elevated Temperature on the Properties of Silica Fume and Recycled Rubber-Filled High Strength Concretes (RHSC), HBRC Journal, 13(1), 1-7. DOI: 10.1016 /j.hbrcj.2015.03.002.

[16] Subhash C. Y., Jishnu W. and Ramesh, P. (2015). Strength Loss Contributions During Stages of Heating, Retention and Cooling Regimes for Concretes Advances in Materials Research, 4(1), 13-22. DOI: 10.12989/amr.2015.4.2.013.

[17] Hernndez-Olivares, F. and Barluenga, G. (2004). Fire Performance of Recycled Rubber-Filled High-Strength Concrete, Cement and Concrete Research, 34(1),109-117. DOI: 10.1016/S0008-8846(03)00253-9.

[18] Guelmine, L., Hadjab, H. and Benazzouk, A. (2016). Effect of Elevated Temperatures on Physical and Mechanical Properties of Recycled Rubber Mortar, Construction and Building Materials, 126, 77-85.

DOI: $10.1016 /$ j.conbuildmat.2016.09.018.

[19] Roeder, C.W., Cameron, B. and Brown, C.B., (1999). Composite Action in Concrete Filled Tubes, Journal of structural engineering, 125(5), 477-484. DOI: 10.1061/(ASCE)0733-9445(1999)125:5(477).

[20] Parsley, M. and Yura, J. (2000). Push-out Behavior of Rectangular Concrete-Filled Steel Tubes, Special Publication,196, 87-108.

[21] Nezamian, A., Al-Mahaidi, R. and Grundy, P., (2006). Bond Strength of Concrete Plugs Embedded in Tubular Steel Piles under Cyclic Loading, Canadian Journal of Civil Engineering, 33(2), 111-125. DOI: 10.1139/105-091.

[22] De Nardin, S. and El Debs, A., (2007). Shear Transfer Mechanisms in Composite Columns: an Experimental Study, Steel and Composite Structures, 7(5), 377-390. DOI: 10.12989/scs.2007.7.5.377

[23] Aly, T., Elchalakani, M., Thayalan, P.Patnaikuni,I, (2010). Incremental Collapse Threshold for Pushout Resistance of Circular Concrete Filled Steel Tubular Columns, Journal of Constructional Steel Research, 66(1), 11-18. DOI: $1.1016 /$ j.jcsr.2009.08.002

[24] Liu, Z.Y. (2012). Experiment Study on Interfacial Normal Bond Strength of Concrete Filled Steel Tube, Advanced Materials Research. 947-954 DOI: 10.4028/www.scientific.net/AMR.594-597.947

[25] Lihong, X. and Shaohuai, C. (1996). Bond Strength at the Interface of Concrete-filled Steel Tube Columns, Building Science, 3.

[26] Qu, X., Chen, Z., Nethercot, D.A., Gardner, L. and Theofanous, M., (2015). Push-out Tests and Bond Strength of Rectangular CFST Columns, Steel and Composite Structures, 19(1), 21-41.

[27] Hunaiti, Y.M., (1991). Bond Strength in Battened Composite Columns Journal of Structural Engineering, 117(3), 699714. DOI: 10.1061/(ASCE)0733-9445(1991)117:3(699).

[28] Tao, Z., Han, L.H, Uy, B. and X., (2011). Post-Fire Bond Between the Steel Tube and Concrete in Concrete-Filled Steel Tubular Columns, Journal of Constructional Steel Research, 67(3), 484-496. DOI: 10.1016/j.jcsr.2010.09.006.

[29] ECP: ECP-203: (2007). Egyptian code for design and construction of reinforced concrete structures, Housing and Building National Research Center. Ministry of Housing, Utilities and Urban Planning, Cairo.

[30] Siddique, R. and Naik, T.R. (2004). Properties of Concrete Containing Scrap-Tire Rubber-An Overview, Waste management, 24(6),563-569. DOI: 10.1016/j.wasman.2004.01.006.

[31] Ganjian, E., Khorami, M. and Maghsoudi, A.A. (2009). Scrap-Tyre-Rubber Replacement for Aggregate and Filler in Concrete, Construction and building materials, 23(5), 1828-1836. DOI: 10.1016/ j.conbuildmat.2008.09.020.

[32] [32] Aslani, F., (2015). Mechanical Properties of Waste Tire Rubber Concrete, Journal of Materials in Civil Engineering, 28(3) 04015152. DOI: 10.1061/(ASCE)MT.1943-5533.0001429. 
[33] States, J., (2011). Investigation of Crumb Rubber Concrete for Blast Protection of Buildings, MSC thesis, Lehigh University.

[34] Sofi, A., (2017). Effect of Waste Tyre Rubber on Mechanical and Durability Properties of Concrete-A Review, Ain Shams Engineering Journal, DOI: 10.1016/j.asej.2017.08.007.

[35] Turatsinze, A., Granju, J.L. and Bonnet, S. (2006). Positive Synergy Between Steel-Fibres and Rubber Aggregates: Effect on The Resistance of Cement-Based Mortars to Shrinkage Cracking, Cement and concrete research, 36(9), 1692-1697. DOI: 10.1016/j.cemconres.2006.02.019.

[36] Son, K.S., Hajirasouliha, I. and Pilakoutas, K. (2011). Strength and Deformability of Waste Tyre Rubber-Filled Reinforced Concrete Columns, Construction and building materials, 25(1), 218-226. DOI: 10.1016/j.conbuildmat.2010.06.035.

[37] Netinger, I., Kesegic, I. and Guljas, I., (2011). The Effect of High Temperatures on The Mechanical Properties of Concrete Made with Different Types of Aggregates, Fire safety journal, 46(7), 425-430. DOI: 10.1016/j.firesaf.2011.07.002 .

[38] Uysal, M., Yilmaz, K. and Ipek, M., (2012). Properties and Behavior of Self-Compacting Concrete Produced with Gbfs and Fa Additives Subjected to High Temperatures, Construction and Building Materials, 28(1), 321-326. DOI: 10.1016/j.conbuildmat.2011.08.076.

[39] Janotka, I. and Nürnbergerová, T., (2005). Effect of Temperature on Structural Quality of the Cement Paste and HighStrength Concrete with Silica Fume, Nuclear Engineering and design, 235(17-19), 2019-2032. DOI: 10.1016/j.nucengdes.2005.05.011.

[40] Wium, J.A. and Lebet, J.P. (1994). Simplified calculation method for force transfer in composite columns, Journal of Structural Engineering, 120(3), 728-746. DOI: 10.1061/(ASCE)0733-9445(1994)120:3(728).

[41]Johansson, M. and Gylltoft, K. (2002). Mechanical Behavior of Circular Steel-Concrete Composite Stub Columns, Journal of structural engineering,. 128(8) 1073-1081. DOI: 10.1061/(ASCE)0733-9445(2002)128:8(1073).

[42] Qu, X., Chen, Z., Nethercot, D.A., Gardner, L. and Theofanous, M., (2013). Load-Reversed Push-Out Tests on Rectangular CFST Columns, Journal of Constructional Steel Research, 81, 35-43. DOI: 10.1016 /j.jcsr.2012.11.003.

[43] Virdi, K. and Dowling, P., (1980). Bond Strength in Concrete Filled Circular Steel Tubes, IABSE Proceedings, 125139.

[44] Han L.H., (2002). Tests on Stub Columns of Concrete-Filled RHS Sections, J Construct Steel Res, 58(3): 353-372. DOI: 10.1016/S0143-974X(01)00059-1.

[45] Chen, Z.H., Qu, X.S., Wang, X.D., Sun, R.R. and Li, L.M. (2009). Experimental Study on the Interface Bearing Capacity on Concrete-Filled Square Steel Tube, J. Harbin Inst. Tech. 41 (2) 27-32.

[46] Khoury GA. (2006). Strain of Heated Concrete During Two Thermal Cycles. Part 1: Strain Over Two Cycles, During First Heating and at Subsequent Constant Temperature, Magazine of Concrete Research, 58(6), 367-385.

DOI: $10.1680 /$ macr.2006.58.6.367 